\title{
Regional Consumer Hydrogen Demand and Optimal Hydrogen Refueling Station Siting
}

Technical Report NREL/TP-540-42224

April 2008

M. Melendez and A. Milbrandt 


\section{Regional Consumer Hydrogen Demand and Optimal Hydrogen Refueling Station Siting}

M. Melendez and A. Milbrandt

Prepared under Task No. H2782700
Technical Report NREL/TP-540-42224

April 2008

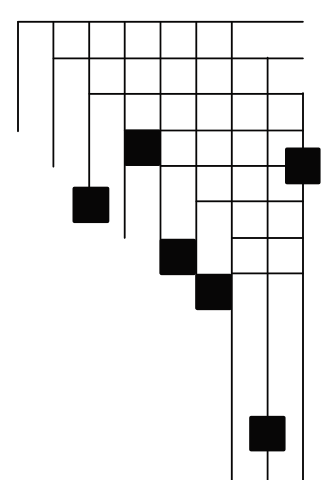




\section{NOTICE}

This report was prepared as an account of work sponsored by an agency of the United States government. Neither the United States government nor any agency thereof, nor any of their employees, makes any warranty, express or implied, or assumes any legal liability or responsibility for the accuracy, completeness, or usefulness of any information, apparatus, product, or process disclosed, or represents that its use would not infringe privately owned rights. Reference herein to any specific commercial product, process, or service by trade name, trademark, manufacturer, or otherwise does not necessarily constitute or imply its endorsement, recommendation, or favoring by the United States government or any agency thereof. The views and opinions of authors expressed herein do not necessarily state or reflect those of the United States government or any agency thereof.

Available electronically at http://www.osti.gov/bridge

Available for a processing fee to U.S. Department of Energy and its contractors, in paper, from:

U.S. Department of Energy

Office of Scientific and Technical Information

P.O. Box 62

Oak Ridge, TN 37831-0062

phone: 865.576 .8401

fax: 865.576 .5728

email: mailto:reports@adonis.osti.gov

Available for sale to the public, in paper, from:

U.S. Department of Commerce

National Technical Information Service

5285 Port Royal Road

Springfield, VA 22161

phone: 800.553.6847

fax: 703.605.6900

email: orders@ntis.fedworld.gov

online ordering: http://www.ntis.gov/ordering.htm 


\section{Table of Contents}

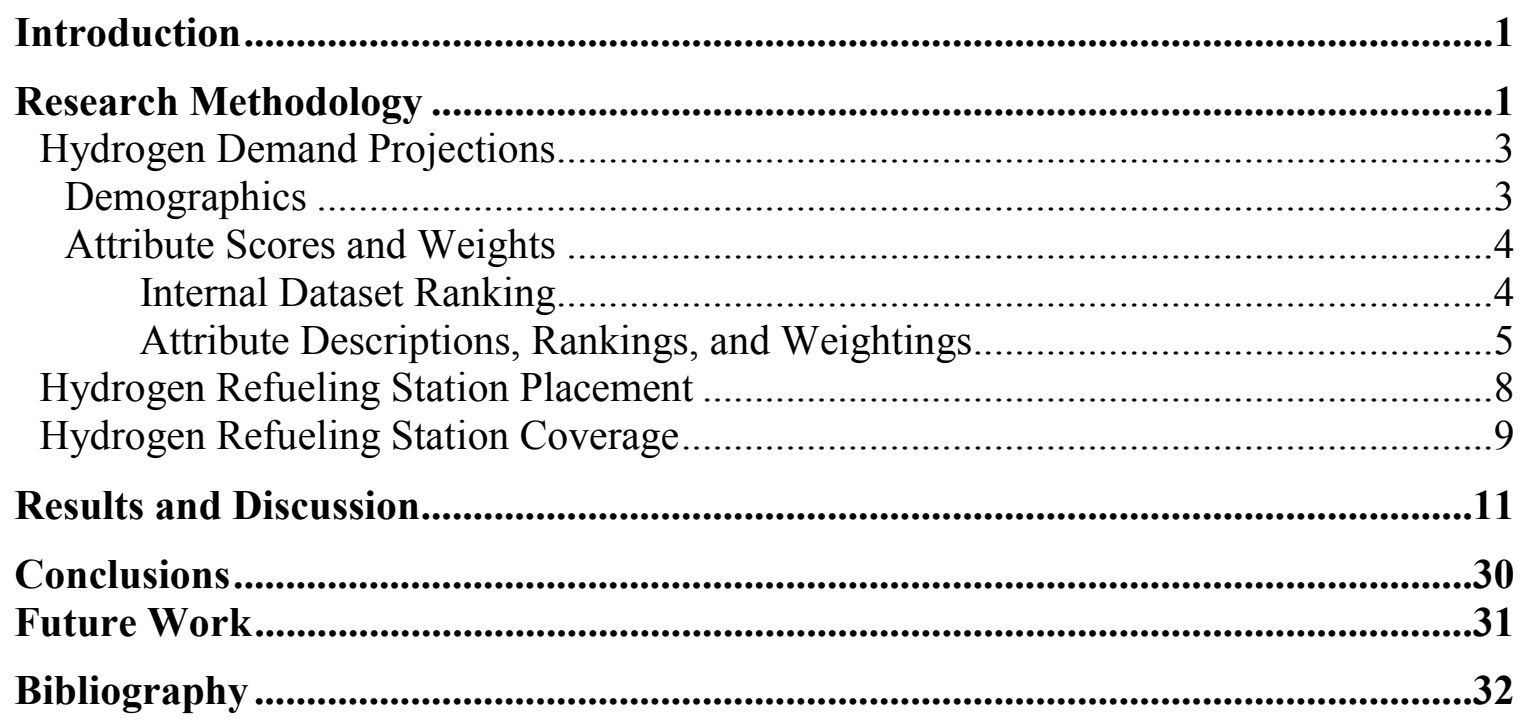

\section{List of Figures}

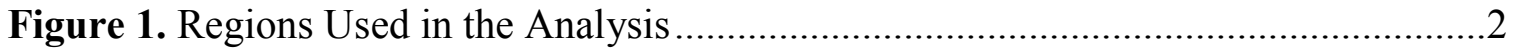

Figure 2. Interstate Highway Hydrogen Fueling Stations Proposed in FY 2005 ...............9

Figure 3. Example of Station Siting Criteria, Denver Subregion .....................................10

Figure 4. Central Region Hydrogen Infrastructure Demand and Subregions....................11

Figure 5. Midwest Region Hydrogen Infrastructure Demand and Subregions..................12

Figure 6. Northeast Region Hydrogen Infrastructure Demand and Subregions ................13

Figure 7. Pacific Region Hydrogen Infrastructure Demand and Subregions ....................14

Figure 8. Southeast Region Hydrogen Infrastructure Demand and Subregions ................15

Figure 9. Proposed Hydrogen Stations in Denver Subregion ...........................................16

Figure 10. Proposed Hydrogen Stations in East Texas Subregion ...................................17

Figure 11. Proposed Hydrogen Stations in Salt Lake City Subregion................................18

Figure 12. Proposed Hydrogen Stations in Chicago Subregion..........................................19

Figure 13. Proposed Hydrogen Stations in Detroit Subregion.........................................20

Figure 14. Proposed Hydrogen Stations in Minneapolis - St. Paul Subregion ..................21

Figure 15. Proposed Hydrogen Stations in St. Louis Subregion .....................................22

Figure 16. Proposed Hydrogen Stations in Philadelphia-New York-Boston Subregion ..23

Figure 17. Proposed Hydrogen Stations in Washington - Baltimore Subregion ...............24 
Figure 18. Proposed Hydrogen Stations in Southern California Subregion ....................25

Figure 19. Proposed Hydrogen Stations in Phoenix Subregion......................................26

Figure 20. Proposed Hydrogen Stations in Seattle - Portland Subregion ........................27

Figure 21. Proposed Hydrogen Stations in Northern California Subregion ....................28

Figure 22. Proposed Hydrogen Stations in Atlanta Subregion .......................................29 


\section{Introduction}

Infrastructure development analysis explores the benefits and drawbacks of various options for installing refueling hardware to serve an emerging hydrogen demand. Most alternative fuel experts agree that infrastructure issues have been among the top barriers to transitioning to alternative transportation fuels. Therefore, infrastructure analysis is a key component in the development of a hydrogen transportation system. Understanding consumer demand on a geographic basis is an important part of this analysis. Matching emerging hydrogen demand with emerging infrastructure is critical to a successful transition.

In fiscal years (FY) 2004 and 2005, the National Renewable Energy Laboratory (NREL) developed a proposed minimal infrastructure to support nationwide deployment of hydrogen vehicles by offering infrastructure scenarios that facilitated interstate travel. ${ }^{1}$ In FY 2006, additional analyses quantified projected hydrogen vehicle demand nationwide and in targeted metropolitan areas and projected hydrogen fuel demand to inform infrastructure decisions (e.g., siting hydrogen refueling stations and selecting between centralized and distributed hydrogen production). ${ }^{2}$

The current (FY 2007) project builds on this previous work by analyzing projected hydrogen demand at a finer (subregional) scale and proposing hypothetical locations for hydrogen refueling stations based on optimal demand characteristics. The following are the objectives of this analysis:

1. Identify the minimum hydrogen infrastructure needed to gain consumer buy-in for purchasing hydrogen vehicles .

2. Demonstrate a method for siting hydrogen stations based on the unique demand characteristics of select urban areas.

\section{Research Methodology}

There are two general types of vehicle purchasers: 1) consumers and 2) fleets. Both groups have unique characteristics that affect how they choose vehicles to purchase and drive. This study examines hydrogen infrastructure demand based on anticipated hydrogen vehicle owners.

Various factors influence a consumer's vehicle purchase decision, including purchaser characteristics (e.g., income and age) and external factors (e.g., vehicle rebates, interest

\footnotetext{
${ }^{1}$ See Melendez, M.; Milbrandt, A. Analysis of the Hydrogen Infrastructure Needed to Enable Commercial Introduction of Hydrogen-Fueled Vehicles: Preprint. NREL Report No. CP-540-37903. Golden, CO: National Renewable Energy Laboratory, 2005.

${ }^{2}$ See Melendez, M.; Milbrandt, A. Geographically Based Hydrogen Consumer Demand and Infrastructure Analysis: Final Report. NREL Report No. TP-560-40373. Golden, CO: National Renewable Energy Laboratory, 2006.
} 
rates, and tax incentives). To match emerging consumer demand for hydrogen vehicles with transitional hydrogen infrastructure, the spatial/geographic component of consumer demand must be understood. This analysis projects the geographic distribution of consumer demand for hydrogen vehicles and the corresponding infrastructure requirements.

The analysis consists of the following steps:

- Project Hydrogen Demand at Census Tract Level: Key attributes affecting consumer acceptance of hydrogen vehicles are identified and spatially analyzed at the census tract level using geographic information systems (GIS).

- Site Hydrogen Refueling Stations: Specific sites for hydrogen refueling stations are suggested based on locations with optimal demand characteristics.

- Quantify Hydrogen Refueling Station Coverage: The proportions of the target populations served by the proposed hydrogen refueling stations are calculated.

A regional framework was used for the analysis. Regions are states grouped together based on physical, demographic, and transportation characteristics (Figure 1). These regions are slightly modified versions of the regions defined by the U.S. Census Bureau (e.g., the Rocky Mountain and Great Plains states are combined into a single Central Region owing to their low population, small urban areas, and relative isolation from highly populated areas).

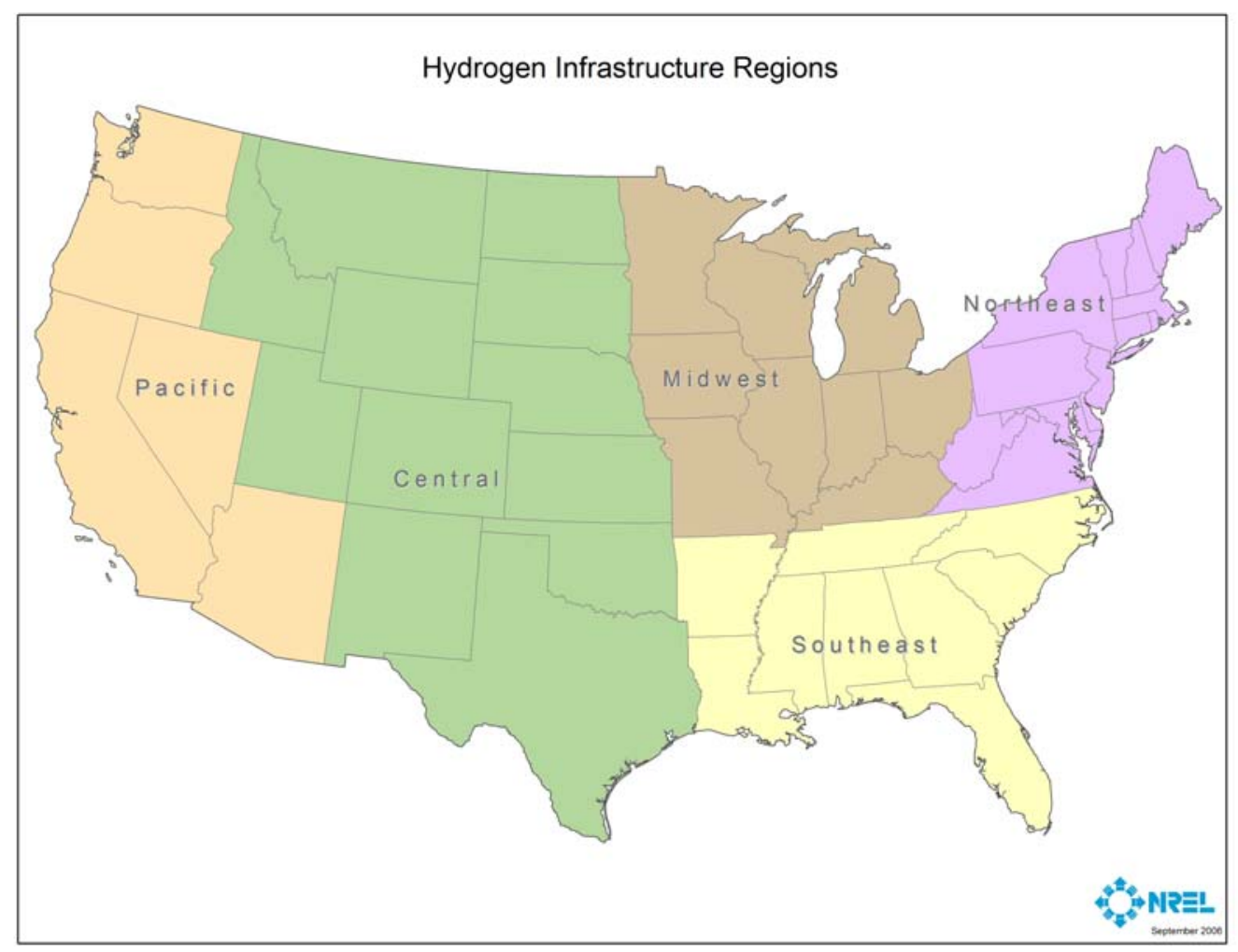

Figure 1. Regions Used in the Analysis 
Once projected hydrogen demand is calculated, subregions are identified within the regions. Subregions are large urban areas or clusters of urban areas with contiguous "good" and higher hydrogen demand and well-established traffic corridors. This regional/subregional framework balances the demand analysis and proposed hydrogen infrastructure throughout the nation and ensures that geographically diverse urban areas are examined.

\section{Hydrogen Demand Projections}

\section{Demographics}

Key attributes affecting hydrogen vehicle penetration into the consumer market were identified through a literature search (from the FY 2004 and 2005 work described in the Introduction above) and interviews with vehicle technology transition experts, then reviewed and ranked by a focus group consisting of NREL personnel with expertise in advanced technology vehicle deployment (Table 1). These assumptions were also confirmed by various market studies and analyses related to hybrid and hydrogen vehicles conducted by researchers at UC Davis and Synovate.

Table 1. Attributes Affecting Hydrogen Vehicle Adoption by Consumers

\begin{tabular}{|c|c|c|}
\hline Attribute & Impact & Rationale \\
\hline Household Income & High & Higher incomes lead to earlier adoption \\
\hline $\begin{array}{l}\text { Households with Two or More } \\
\text { Vehicles }\end{array}$ & High & $\begin{array}{l}\text { Households with multiple vehicles more likely to } \\
\text { adopt hydrogen vehicles }\end{array}$ \\
\hline Air Quality & Medium & $\begin{array}{l}\text { Low air quality leads to educated consumers and } \\
\text { incentives }\end{array}$ \\
\hline Clean Cities Coalitions & Medium & $\begin{array}{l}\text { Coalitions pull funding opportunities together and } \\
\text { create alternative fuel awareness }\end{array}$ \\
\hline Commute Distance & Medium & $\begin{array}{l}\text { More time spent commuting in a vehicle interests } \\
\text { consumers in newer and more efficient vehicles }\end{array}$ \\
\hline Education & Medium & Higher education leads to earlier adoption \\
\hline Hybrid Vehicle Registrations & Medium & $\begin{array}{l}\text { Early adopters of new gasoline vehicle } \\
\text { technologies could be early adopters of new } \\
\text { hydrogen vehicle technologies }\end{array}$ \\
\hline State Incentives & Medium & $\begin{array}{l}\text { Alternative fuel vehicle incentives could indicate } \\
\text { future or existing hydrogen incentives }\end{array}$ \\
\hline $\begin{array}{l}\text { Zero-Emission Vehicle (ZEV) } \\
\text { Sales Mandate }\end{array}$ & Medium & Hydrogen vehicles qualify for these mandates \\
\hline
\end{tabular}

These attributes apply to a strategy where the general public consumer, limited to the contiguous United States, is the primary focus of early hydrogen vehicle deployment. Hydrogen vehicle demand can be described as a function of these attributes:

$$
\text { Consumer hydrogen vehicle demand }=\mathrm{F} \text { (attributes) }
$$

The data to support analysis of these attributes were collected from various sources, including the U.S. Census Bureau, the U.S. Department of Energy's (DOE) Clean Cities Alternative Fuels Data Center (AFDC), and the U.S. Environmental Protection Agency. 


\section{Attribute Scores and Weights}

The original datasets of each attribute have varying spatial presentations - some are at census tract level ${ }^{3}$, whereas others are at county or state levels or actual locations. For each subregion, all these datasets were aggregated or disaggregated to the census tract level using two standard GIS techniques:

- Area-weighting-Area-weighting is a common form of quantitative aggregation. Data values are multiplied by the percentage of the area a component covers and then divided by the total of the area percentages.

- Dominant component-Dominant component is applied to qualitative datasets such as air quality and state incentives. It takes the data value for the component covering the largest area of the tract and assigns that value to the entire tract.

As outlined in Table 1, not all attributes have an equal impact on hydrogen vehicle demand. To incorporate these inequalities into the analysis, preferences were incorporated into the corresponding model developed in ArcGIS 9.1 Model Builder. The Model Builder Spatial Analyst extension evaluates multiple attributes through classification, ranking, and weighted-overlay techniques to produce the results for each demand scenario. The Model Builder is very flexible. Models can be saved and rerun with different parameters. In addition, data can be added or replaced, and other modules can be attached.

In order to perform the analysis effectively, attribute datasets had to be first ranked internally to value the data within the dataset. The attributes were then weighted in relation to other attributes.

\section{Internal Dataset Ranking}

There is no single best data classification method; each has advantages and disadvantages depending on the nature of the data and the type of information and analysis desired. In general, a classification method should maximize the between-class differences and minimize the within-class differences.

The natural breaks classification was chosen for this study. This method identifies break points by looking for groupings and patterns inherent in the data. ArcGIS uses a complex statistical formula (Jenk's Optimization) to identify break points by choosing the class breaks that best group similar value and maximize the differences between classes. The features are divided into classes with boundaries set where there are relatively big jumps in the data values. The major disadvantages are that the concept behind the classification may not be easily understood by all map users, and the legend values for the class breaks may not be intuitive. The advantage, however, is that it is one of the best ways to classify data that model natural human behaviors and patterns. The natural break method best applies to projected hydrogen demand because hydrogen demand patterns are not uniform by nature.

\footnotetext{
${ }^{3}$ A census tract is a small, relatively permanent statistical subdivision of a county, which is relatively homogeneous with respect to population characteristics, economic status, and living conditions. The population of census tracts averages about 4,000. (The U.S. Census Bureau)
} 
Using the natural break classification method, five classes were created within each data layer. Five classes were chosen because of the depth of analysis and the refinement of results they would provide. Then, a ranking system of 1 to 5 was employed to rate the values within each class used in the hydrogen demand model. A class was ranked 1 if its values had a "low" influence on the chosen strategy (e.g., people with the lowest income would generate the lowest hydrogen vehicle demand). A class was ranked 5 if its values had a "very high" influence (e.g., people with the highest income would generate the highest hydrogen vehicle demand).

\section{Attribute Descriptions, Rankings, and Weightings}

Based on the value placed on the attributes by transportation experts (Table 1), attributes were weighted in relation to each other in ArcGIS in terms of low, medium, or high impact on hydrogen vehicle adoption. These are normalized so the weightings of all the attributes are equal to $100 \%$. The following section describes each attribute as well as the attribute classifications, rankings, and weightings.

- Household Income

- Data origin: 2000 U.S. Census

- Data representation: median household income

- Rationale: Initial customers for hydrogen vehicles will be those with higher income levels.

Table 2. Household Income

\begin{tabular}{|c|c|c|c|}
\hline \multirow{2}{*}{ Attribute } & $\begin{array}{c}\text { Values and } \\
\text { Classification } \\
\text { (median income, } \\
\text { \$U.S.) }\end{array}$ & $\begin{array}{c}\text { Scoring of } \\
\text { Classification }\end{array}$ & \multirow{2}{*}{ Weighting Score } \\
\hline \multirow{3}{*}{ Household Income } & $0-25,000$ & 1 & \multirow{2}{*}{$15 \%$ (High) } \\
\cline { 2 - 3 } & $25,001-50,000$ & 2 & \\
\cline { 2 - 3 } & $50,001-75,000$ & 3 & \\
\cline { 2 - 3 } & $75,001-100,000$ & 4 & 5 \\
\cline { 2 - 3 } & $>100,000$ & 5 & \\
\hline
\end{tabular}

- Households with Two or More Vehicles

- Data origin: 2000 U.S. Census

- Data representation: number of households that have two or more vehicles

- Rationale: Initial customers for hydrogen vehicles will be those in households that have at least two vehicles because of limited hydrogen range and refueling opportunities. (The NREL focus group considered this to be the most important factor in predicting hydrogen vehicle demand.)

Table 3. Households with Two or More Vehicles

\begin{tabular}{|c|c|c|c|}
\hline Attribute & $\begin{array}{l}\text { Values and } \\
\text { Classification } \\
\text { (number of } \\
\text { households) }\end{array}$ & $\begin{array}{l}\text { Scoring of } \\
\text { Classification }\end{array}$ & Weighting Score \\
\hline \multirow{5}{*}{$\begin{array}{l}\text { Two or More Vehicles } \\
\text { per Household }\end{array}$} & $0-100$ & 1 & \multirow{5}{*}{ 15\% (High) } \\
\hline & $101-500$ & 2 & \\
\hline & $501-1,000$ & 3 & \\
\hline & $1,001-2,000$ & 4 & \\
\hline & $>2,000$ & 5 & \\
\hline
\end{tabular}


- Air Quality

- Data origin: U.S. Environmental Protection Agency, 2004

- Data representation: non-attainment status of area (for one or more pollutants)

- Rationale: Issues with local air pollution make consumers more aware of the impacts of vehicles on air pollution and can lead to additional funding or programs for consumers to purchase cleaner vehicles.

\section{Table 4. Air Quality}

\begin{tabular}{|c|c|c|c|}
\hline \multirow{2}{*}{ Attribute } & $\begin{array}{c}\text { Values and } \\
\text { Classification (level } \\
\text { of non-attainment) }\end{array}$ & $\begin{array}{c}\text { Scoring of } \\
\text { Classification }\end{array}$ & \multirow{2}{*}{ Weighting Score } \\
\hline \multirow{3}{*}{ Air Quality } & None & 1 & \multirow{3}{*}{$10 \%$ (Medium) } \\
\cline { 2 - 3 } & Marginal & 3 & \\
\cline { 2 - 3 } & Moderate & 4 & \\
\cline { 2 - 3 } & Severe & 5 & \\
\hline
\end{tabular}

- Clean Cities Coalitions

- Data origin: NREL/DOE Clean Cities Web site, October 2006

- Data representation: existence of Clean Cities Coalition in area

- Rationale: Having a local Clean Cities coordinator to assist in identifying funding, partnerships, and other positive factors in the area is critical to early adoption of hydrogen vehicles.

Table 5. Clean Cities Coalitions

\begin{tabular}{|c|c|c|c|}
\hline Attribute & $\begin{array}{c}\text { Values and } \\
\text { Classification } \\
\text { (Census tract falls } \\
\text { within a Clean City) }\end{array}$ & $\begin{array}{c}\text { Scoring of } \\
\text { Classification }\end{array}$ & Weighting Score \\
\hline $\begin{array}{c}\text { Clean Cities } \\
\text { Coalitions }\end{array}$ & No & 1 & $10 \%$ (Medium) \\
\cline { 2 - 4 } & Yes & 5 & 100 \\
\hline
\end{tabular}

- Commute Distance

- Data origin: 2000 U.S. Census

- Data representation: workers age $16+$ who commute 20 or more minutes each way

- Rationale: More time spent commuting in a vehicle might make consumers more interested in newer and more efficient vehicles.

Table 6. Commute Distance

\begin{tabular}{|c|c|c|c|}
\hline \multirow{2}{*}{ Attribute } & $\begin{array}{c}\text { Values and } \\
\text { Classification } \\
\text { (number of people) }\end{array}$ & $\begin{array}{c}\text { Scoring of } \\
\text { Classification }\end{array}$ & \multirow{2}{*}{ Weighting Score } \\
\hline \multirow{3}{*}{ Commute Distance } & $0-100$ & 1 & \multirow{3}{*}{$10 \%$ (Medium) } \\
\cline { 2 - 3 } & $101-500$ & 2 & \\
\cline { 2 - 3 } & $501-1,000$ & 3 & \\
\cline { 2 - 4 } & $1,001-2,000$ & 5 & 5 \\
\cline { 2 - 3 }
\end{tabular}


- Education

○ Data origin: 2000 U.S. Census

- Data representation: number of people age 25+ with a Bachelor's degree or higher

- Rationale: Initial customers for hydrogen vehicles will be those with higher education levels.

Table 7. Education

\begin{tabular}{|c|c|c|c|}
\hline \multirow{2}{*}{ Attribute } & $\begin{array}{c}\text { Values and } \\
\text { Classification } \\
\text { (number of people) }\end{array}$ & $\begin{array}{c}\text { Scoring of } \\
\text { Classification }\end{array}$ & \multirow{2}{*}{ Weighting Score } \\
\hline \multirow{4}{*}{ Education } & $0-100$ & 1 & \multirow{3}{*}{$10 \%$ (Medium) } \\
\cline { 2 - 3 } & $101-500$ & 2 & \\
\cline { 2 - 3 } & $501-1,000$ & 3 & \\
\cline { 2 - 3 } & $1,001-2,000$ & 5 & 5 \\
\cline { 2 - 3 } & $>2,000$ & & \\
\hline
\end{tabular}

- Hybrid Vehicle Registrations

○ Data origin: R.L. Polk, 2006

- Data representation: number of registered hybrid vehicles

- Rationale: Early adopters of new gasoline vehicle technologies could also be early adopters of new hydrogen vehicle technologies.

\section{Table 8. Registered Hybrid Vehicles}

\begin{tabular}{|c|c|c|c|}
\hline \multirow{2}{*}{ Attribute } & $\begin{array}{c}\text { Values and } \\
\text { Classification } \\
\text { (number of vehicles) }\end{array}$ & $\begin{array}{c}\text { Scoring of } \\
\text { Classification }\end{array}$ & \multirow{2}{*}{ Weighting Score } \\
\hline \multirow{3}{*}{$\begin{array}{c}\text { Registered Hybrid } \\
\text { Vehicles }\end{array}$} & $0-5$ & 1 & \multirow{2}{*}{$10 \%$ (Medium) } \\
\cline { 2 - 3 } & $6-25$ & 2 & \\
\cline { 2 - 3 } & $26-50$ & 3 & 4 \\
\cline { 2 - 3 } & $51-100$ & 5 & \\
\hline
\end{tabular}

- State Incentives

- Data Origin: NREL/DOE Alternative Fuels Data Center (AFDC) Incentives and Laws Web site, January 2006

- Data Representation: number of incentives per state

- Rationale: States with current incentives promoting advanced transportation goals are likely to have such programs in place for hydrogen vehicles.

Table 9. State Incentives

\begin{tabular}{|c|c|c|c|}
\hline \multirow{3}{*}{ Attribute } & $\begin{array}{c}\text { Values and } \\
\text { Classification } \\
\text { (number of } \\
\text { incentives) }\end{array}$ & $\begin{array}{c}\text { Scoring of } \\
\text { Classification }\end{array}$ & Weighting Score \\
\hline \multirow{3}{*}{ State Incentives } & 0 & 1 & \multirow{2}{*}{ 10\% (Medium) } \\
\cline { 2 - 3 } & $1-4$ & 3 & \\
\cline { 2 - 3 } & $5-9$ & 4 & \\
\cline { 2 - 3 } & $10-18$ & 5 & \\
\hline
\end{tabular}


- ZEV Sales Mandate

○ Data origin: NREL/DOE AFDC Incentives and Laws Web site, June 2006

- Data representation: existence of state ZEV mandate

- Rationale: This regulation will increase the likelihood that hydrogen vehicles are offered by manufacturers in these states.

Table 10. ZEV Sales Mandate

\begin{tabular}{|c|c|c|c|}
\hline \multirow{2}{*}{ Attribute } & $\begin{array}{c}\text { Values and } \\
\text { Classification } \\
\text { (existence of } \\
\text { mandate) }\end{array}$ & $\begin{array}{c}\text { Scoring of } \\
\text { Classification }\end{array}$ & Weighting Score \\
\hline ZEV Sales Mandate & No & 1 & $10 \%$ (Medium) \\
\cline { 2 - 4 } & Yes & 5 & 1 \\
\hline
\end{tabular}

\section{Hydrogen Refueling Station Placement}

Once hydrogen demand was calculated using the methodology described above, proposed hydrogen refueling stations were sited based on five factors:

Within 1 mile of major retail stores (Wal-Mart or Costco) or major retail shopping centers

In areas with "good" and higher hydrogen demand

Along major roads or road segments with high traffic volume (above the mean traffic volumes for the area)

In coordination with the previously proposed Interstate Highway stations4 (Figure 2)

Providing balanced station coverage.

GIS was used to site stations near Wal-Mart, Costco, and major retail shopping center locations when the other criteria were met. When multiple locations were identified in the same area (e.g., Wal-Mart and Costco stores across the street from one another), only one station was proposed for that area. The goal was to keep the coverage of hydrogen stations balanced across the urban area.

No target number of stations was established; stations were sited in all locations that met the specified criteria while maintaining balanced coverage. The proposed stations represent an initial hydrogen infrastructure based on current demographics and characteristics of the areas analyzed. Figure 3 shows an example of the station siting criteria, mapped for the Denver subregion.

\footnotetext{
${ }^{4}$ See Melendez, M.; Milbrandt, A. Analysis of the Hydrogen Infrastructure Needed to Enable Commercial Introduction of Hydrogen-Fueled Vehicles: Preprint. NREL Report No. CP-540-37903. Golden, CO: National Renewable Energy Laboratory, 2005.
} 


\section{Hydrogen Refueling Station Coverage}

After the proposed hydrogen stations were sited, the percentage of each subregion's population within 3, 5, and 10 miles of the stations was calculated. ArcGIS Network Analyst was used to create service areas - areas that encompass all accessible streetswithin the specified distances. Service areas represent actual road distance away from stations and because of this are not perfectly circular. Once the service areas were defined, the number of people and proportion of the total subregion population residing within them were calculated.

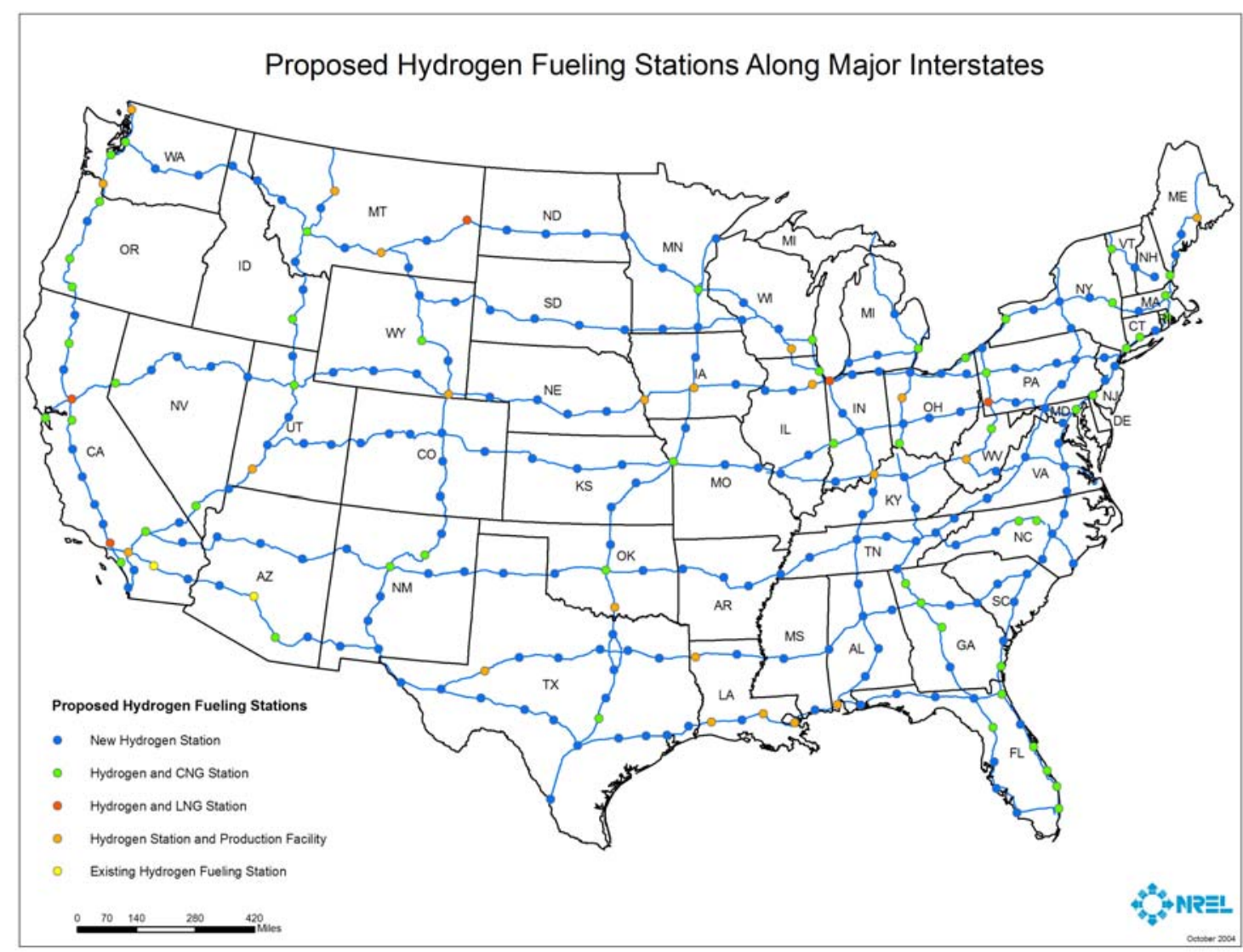

Figure 2. Interstate Highway Hydrogen Fueling Stations Proposed in FY 2005 Analysis 


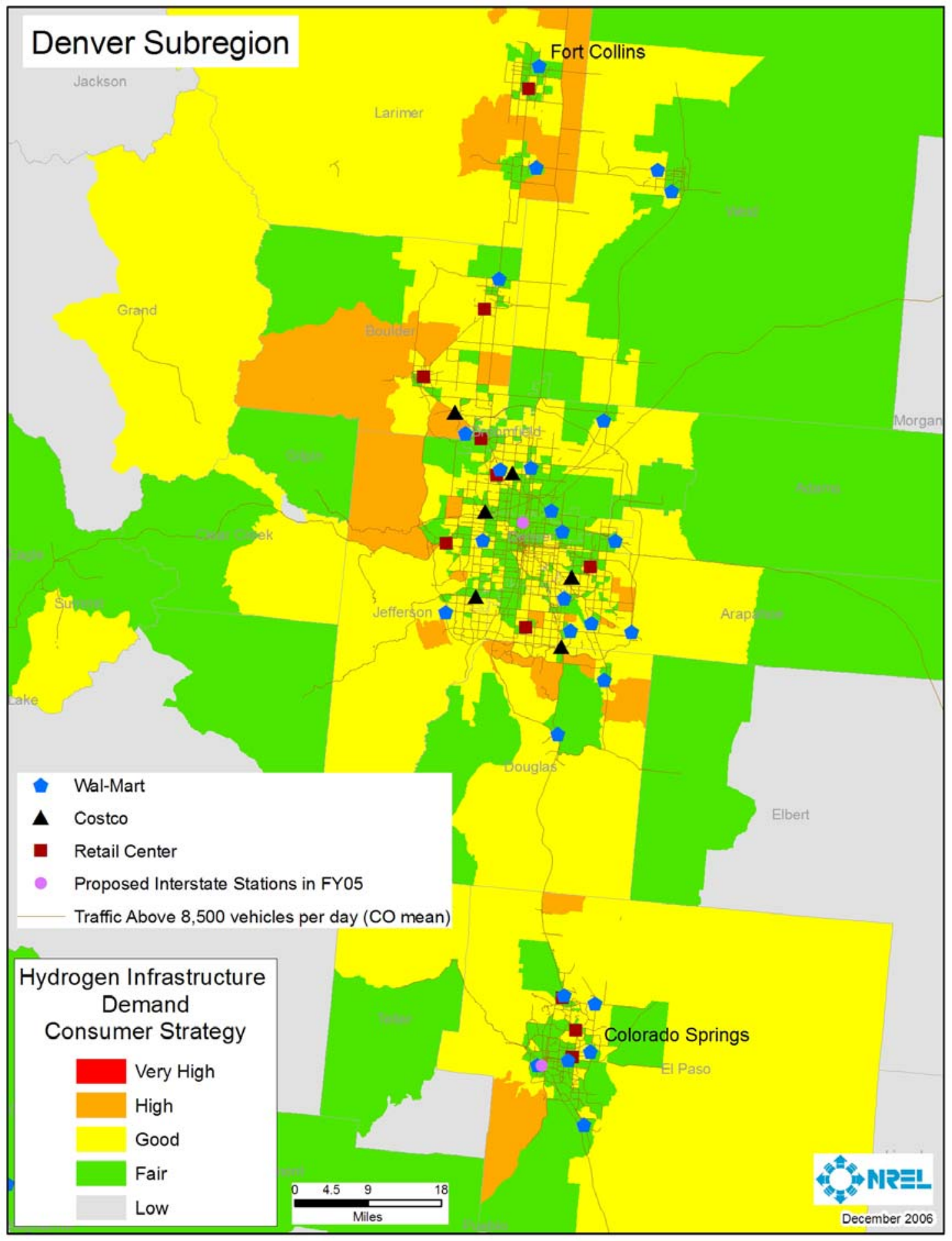

Figure 3. Example of Station Siting Criteria, Denver Subregion 


\section{Results and Discussion}

Figure 4 through Figure 8 show calculated hydrogen infrastructure demand by region and define subregions. Figure 9 through Figure 22 show proposed hydrogen station locations for each subregion.

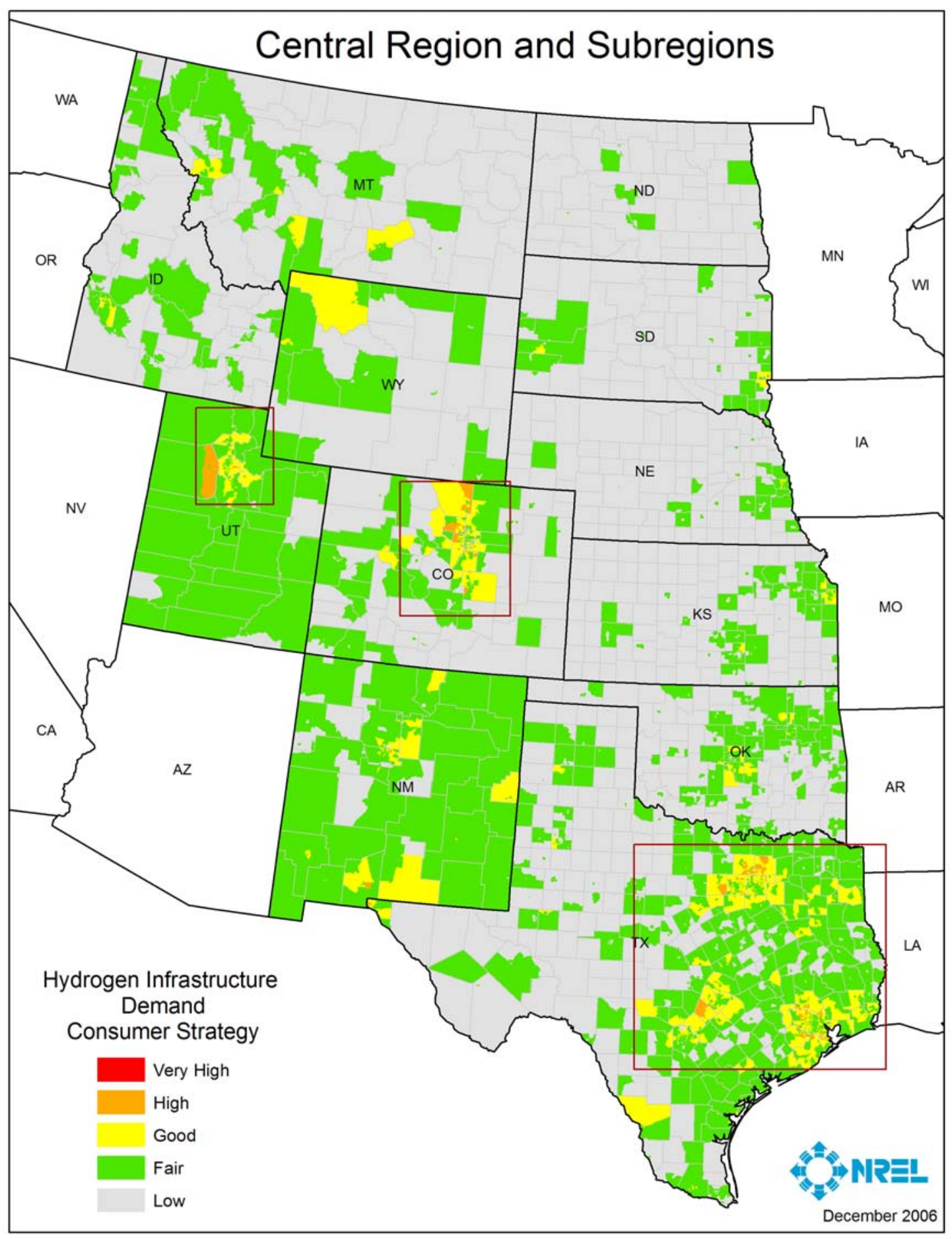

Figure 4. Central Region Hydrogen Infrastructure Demand and Subregions 


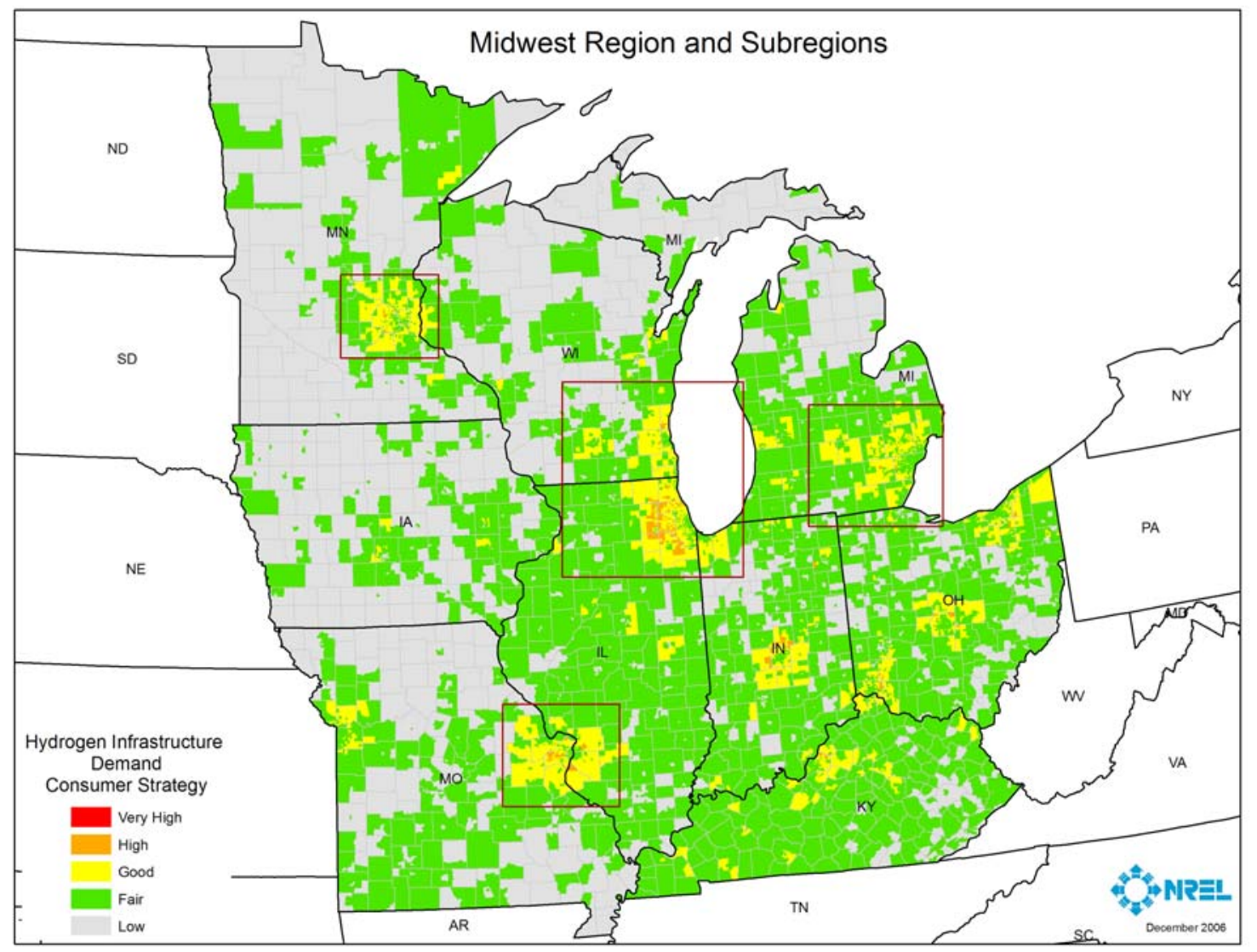

Figure 5. Midwest Region Hydrogen Infrastructure Demand and Subregions 


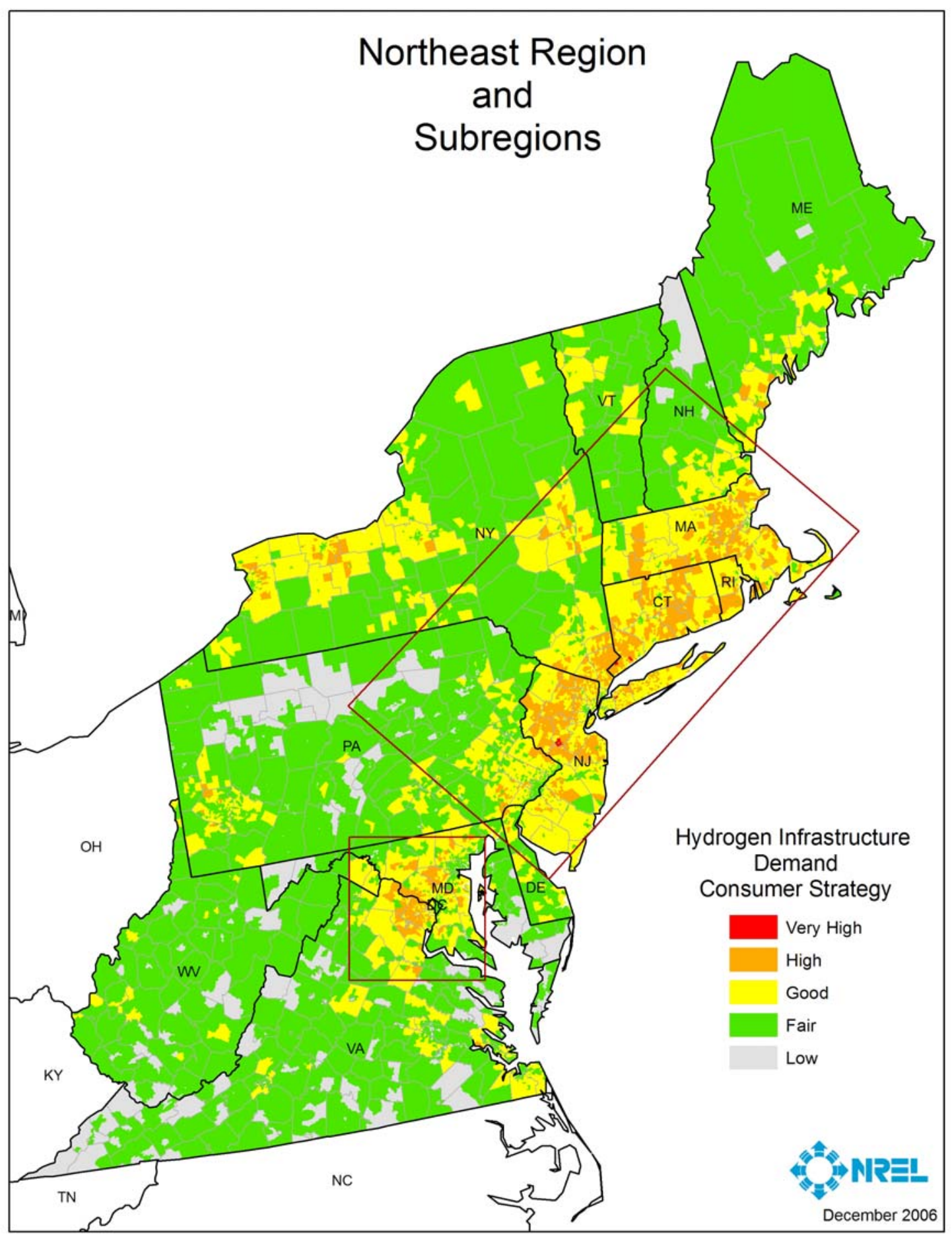

Figure 6. Northeast Region Hydrogen Infrastructure Demand and Subregions 


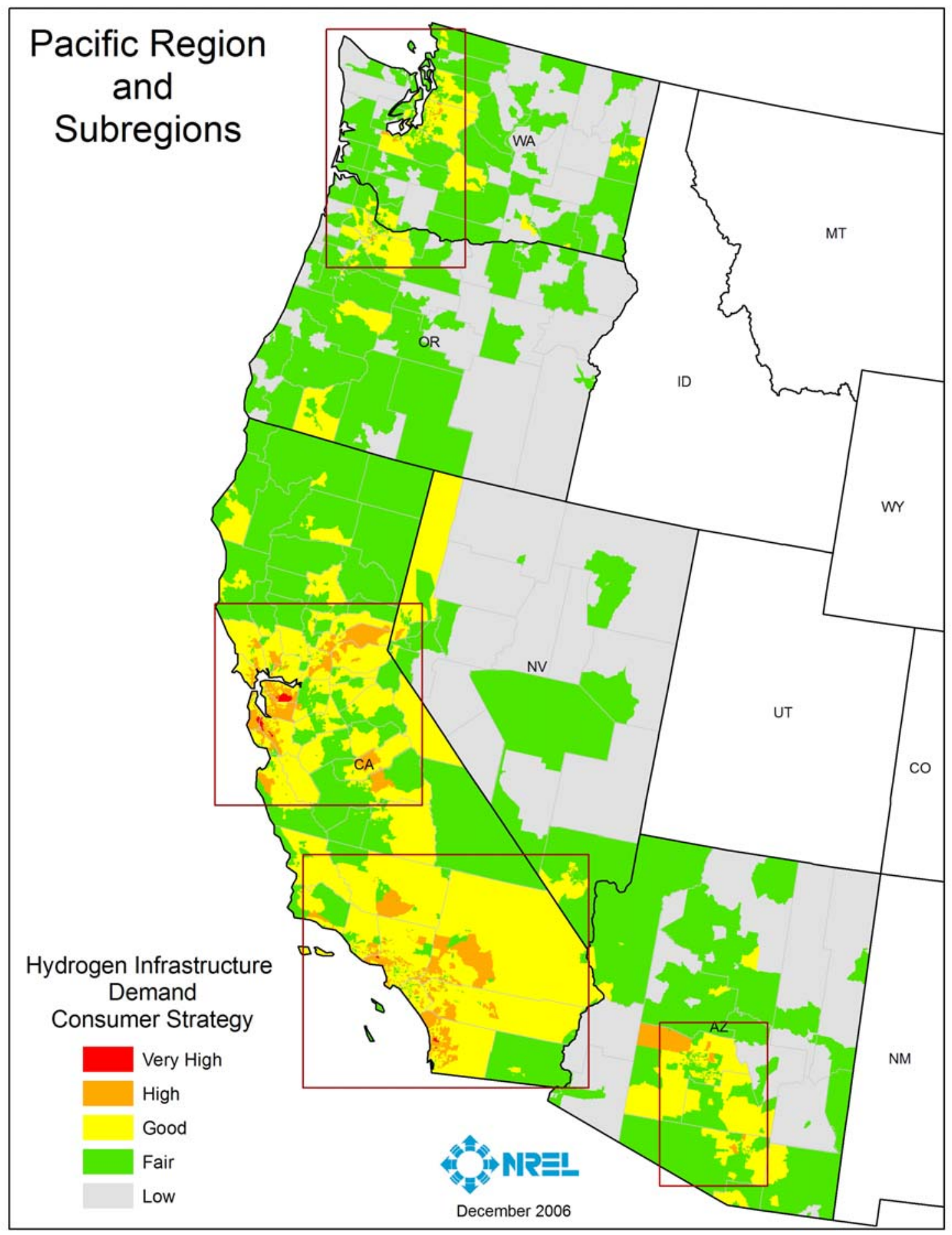

Figure 7. Pacific Region Hydrogen Infrastructure Demand and Subregions 


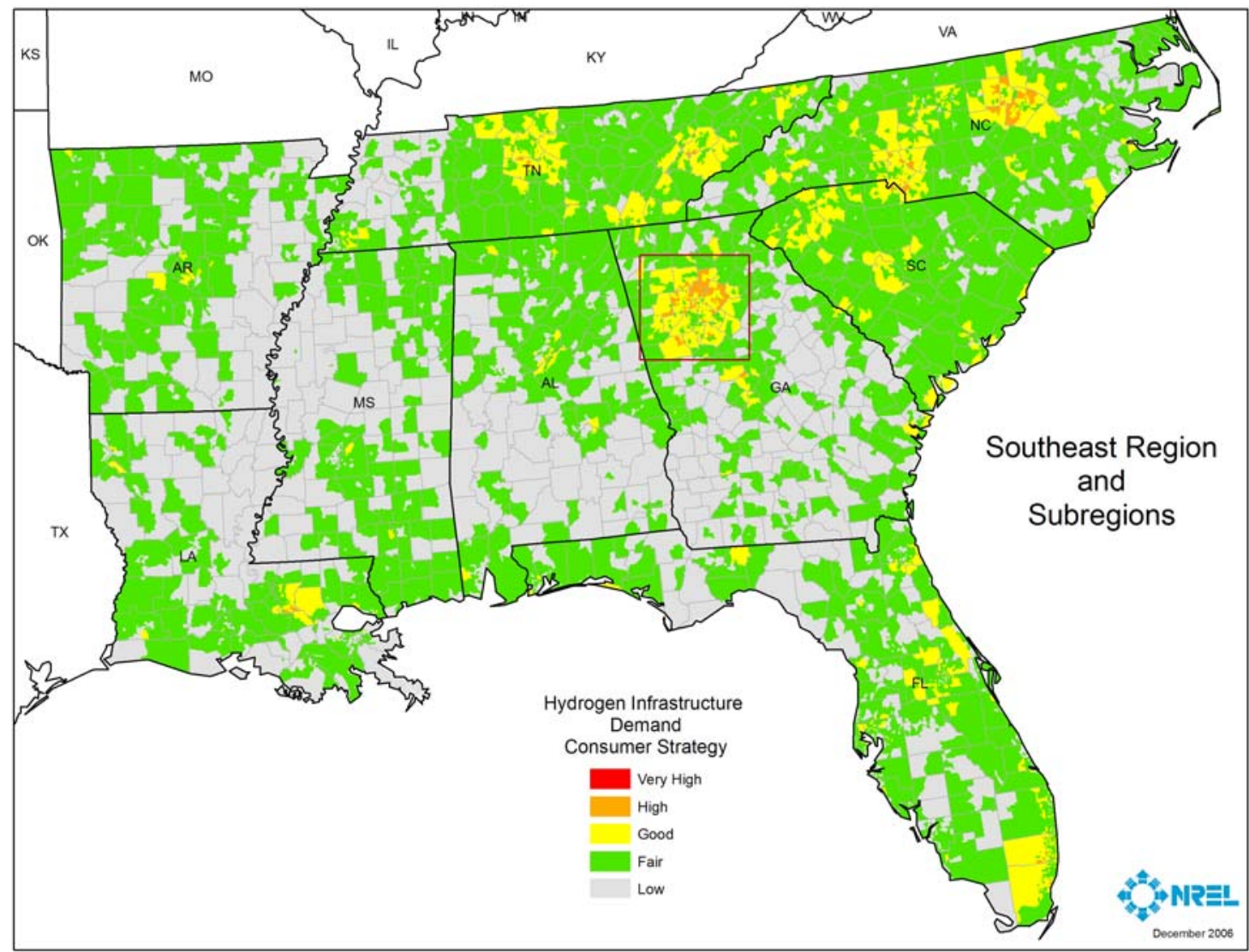

Figure 8. Southeast Region Hydrogen Infrastructure Demand and Subregions 


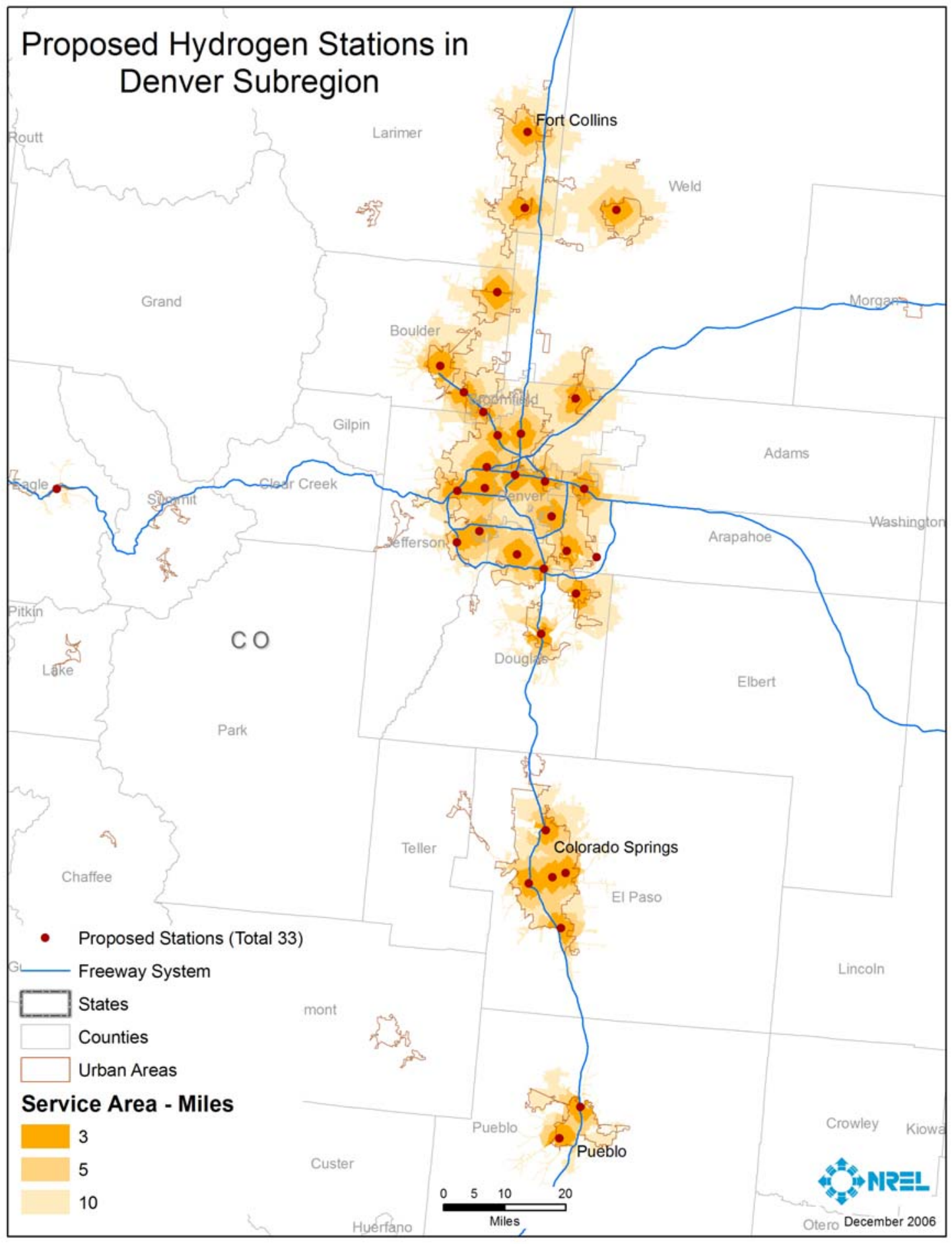

Figure 9. Proposed Hydrogen Stations in Denver Subregion 


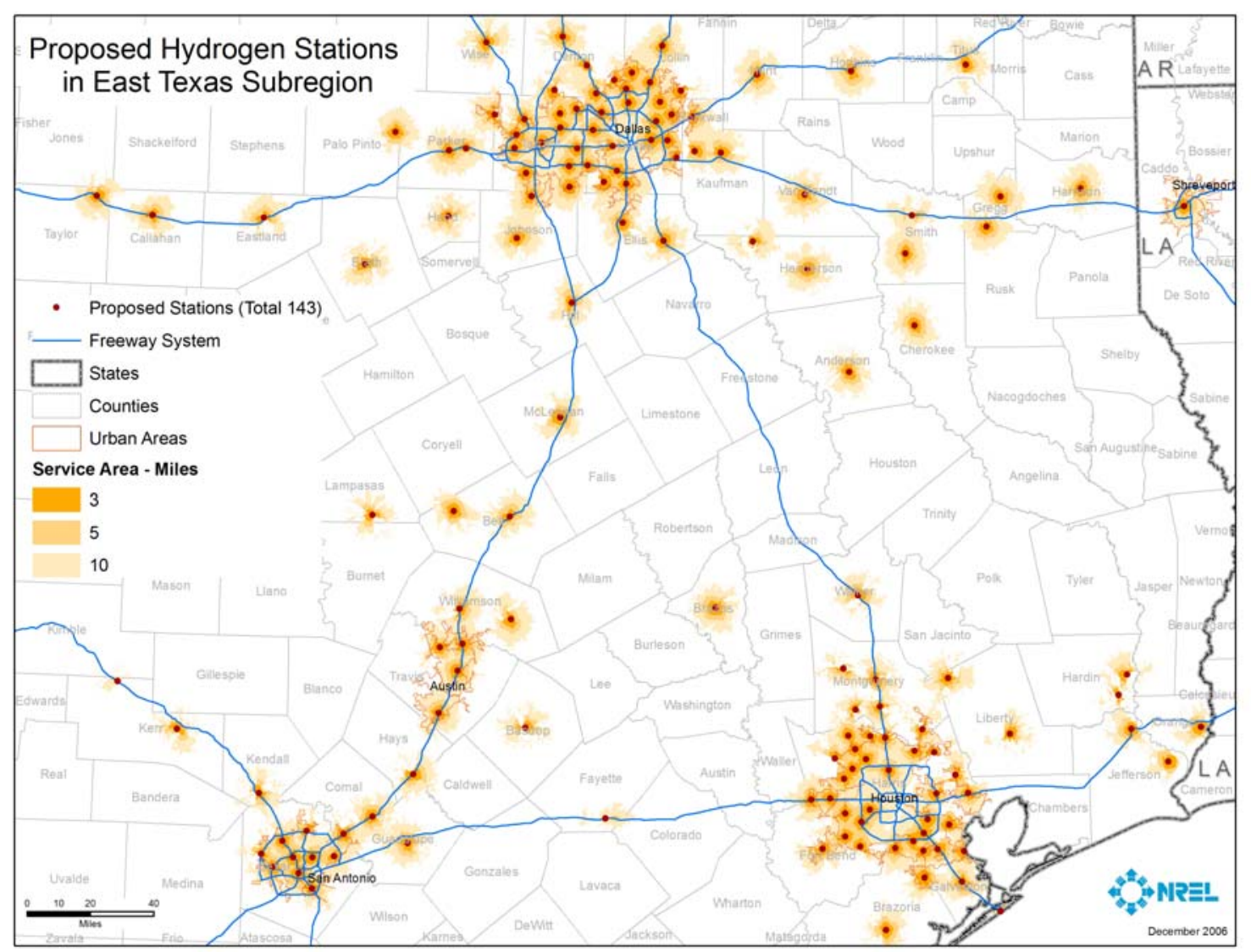

Figure 10. Proposed Hydrogen Stations in East Texas Subregion 


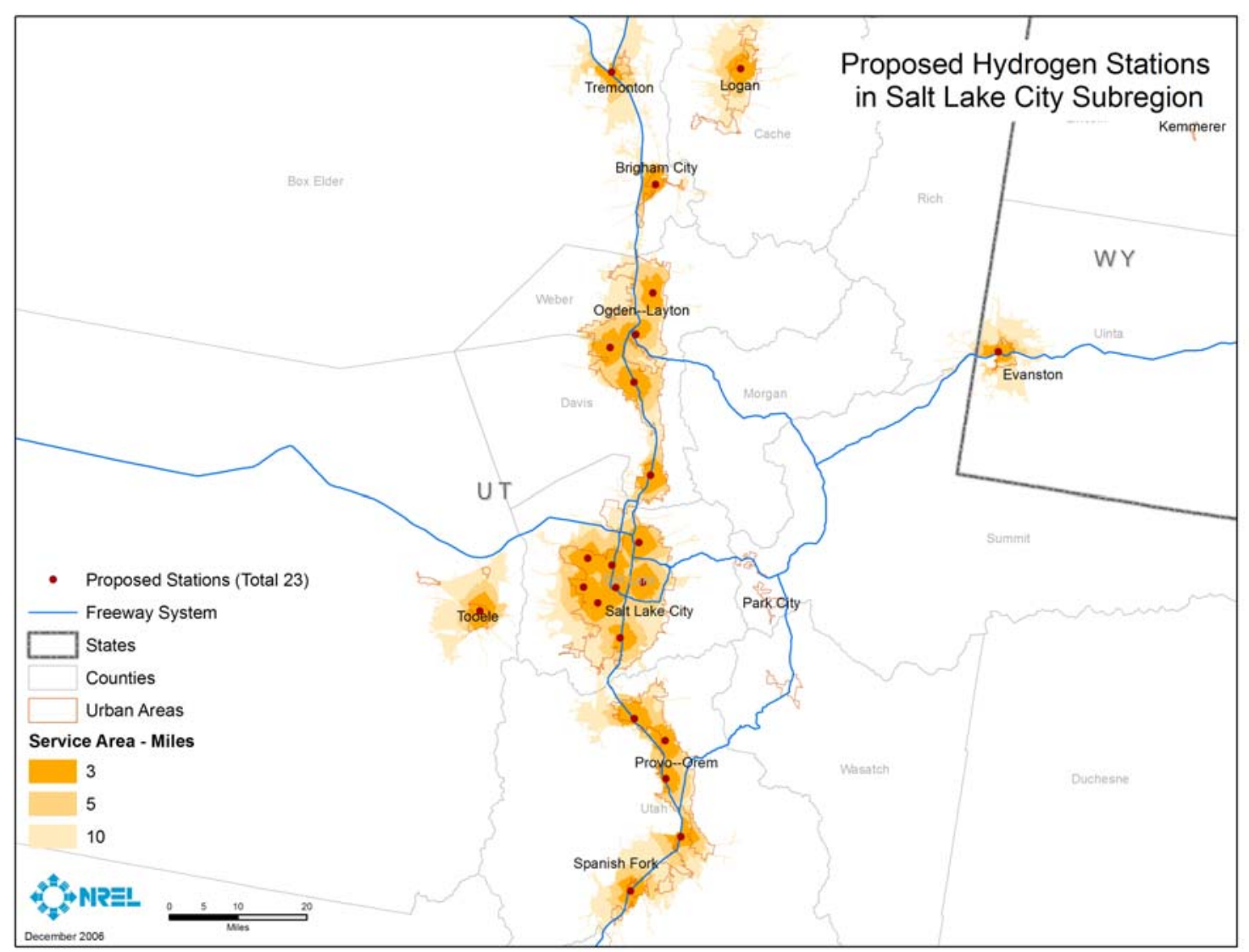

Figure 11. Proposed Hydrogen Stations in Salt Lake City Subregion 


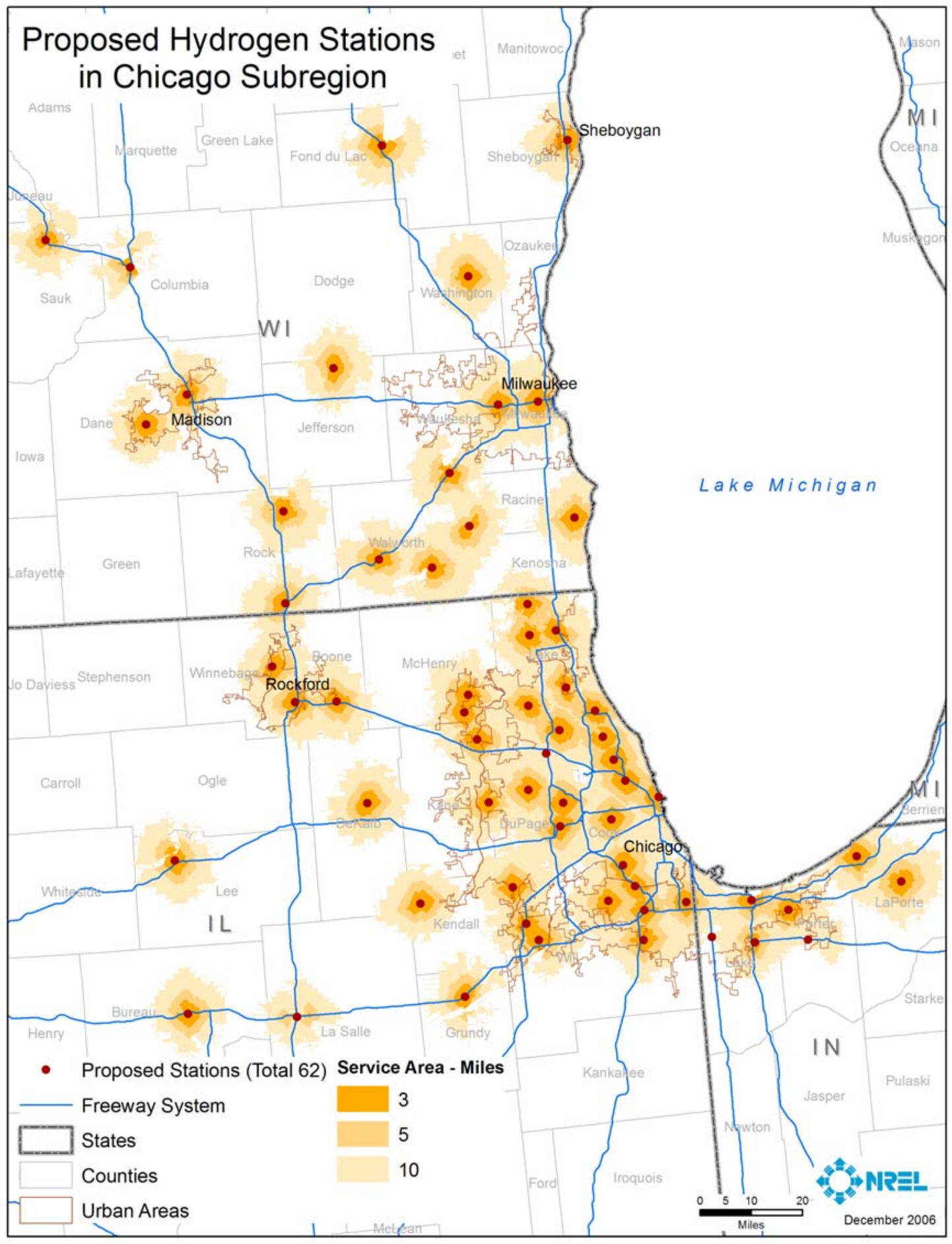

Figure 12. Proposed Hydrogen Stations in Chicago Subregion 


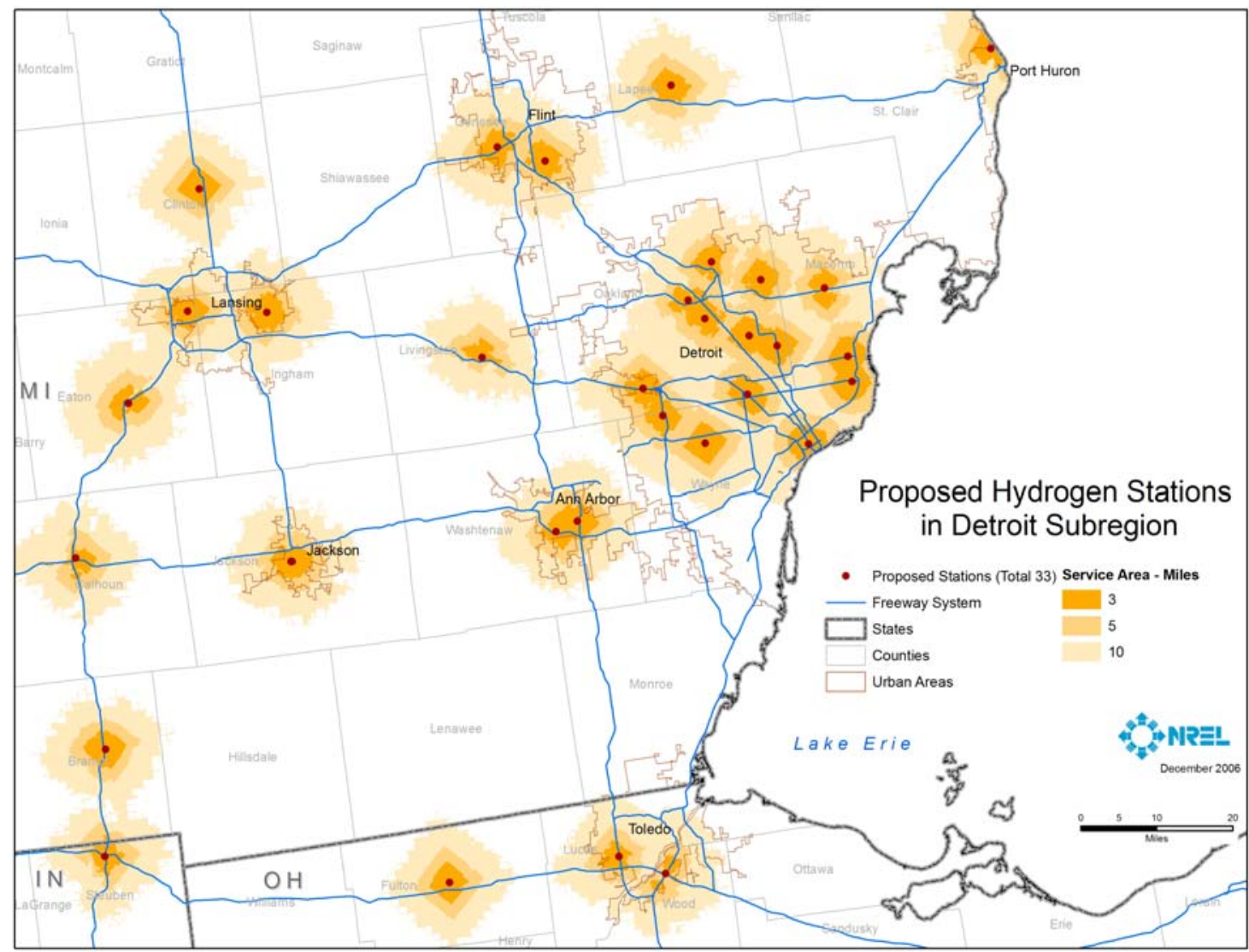

Figure 13. Proposed Hydrogen Stations in Detroit Subregion 


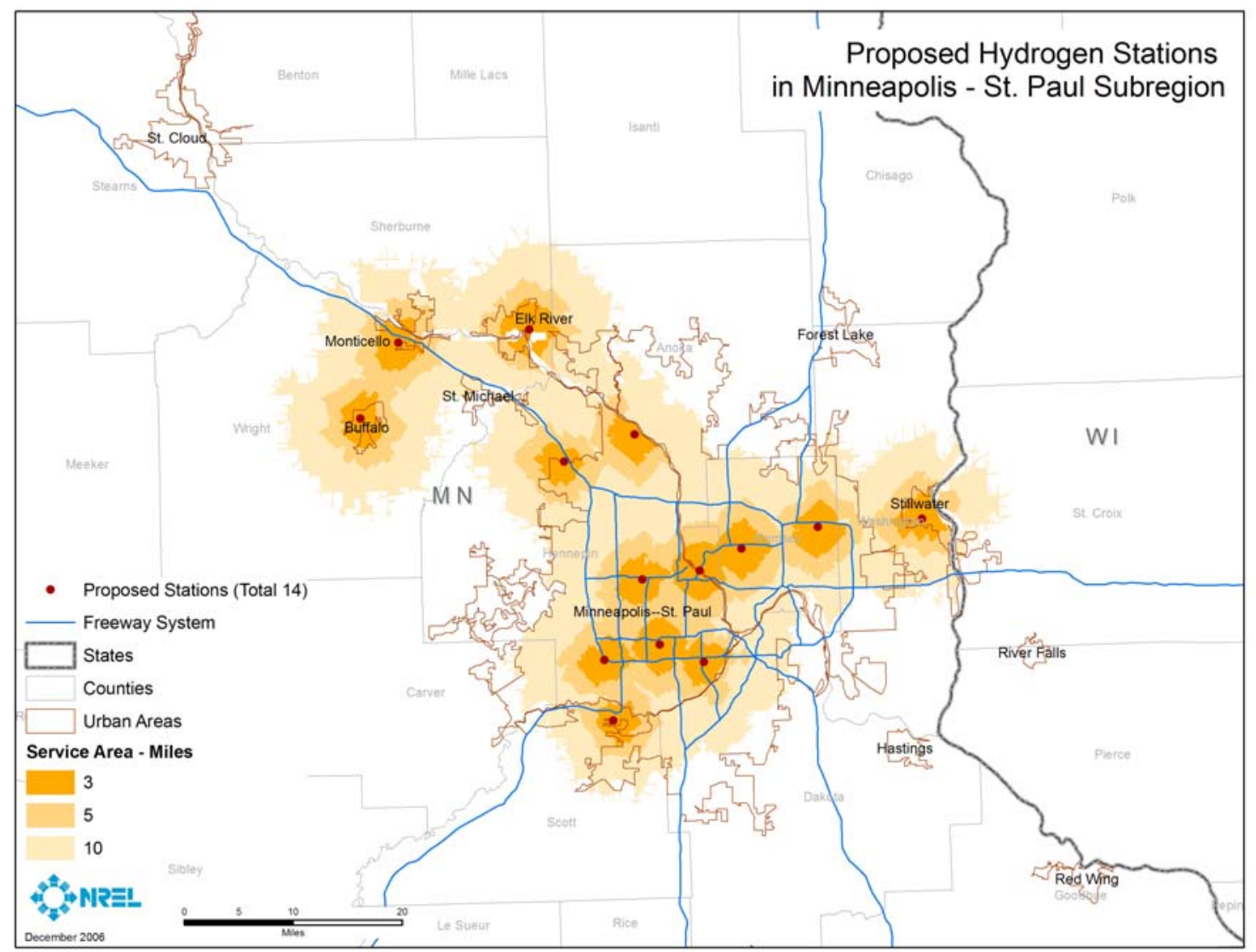

Figure 14. Proposed Hydrogen Stations in Minneapolis - St. Paul Subregion 


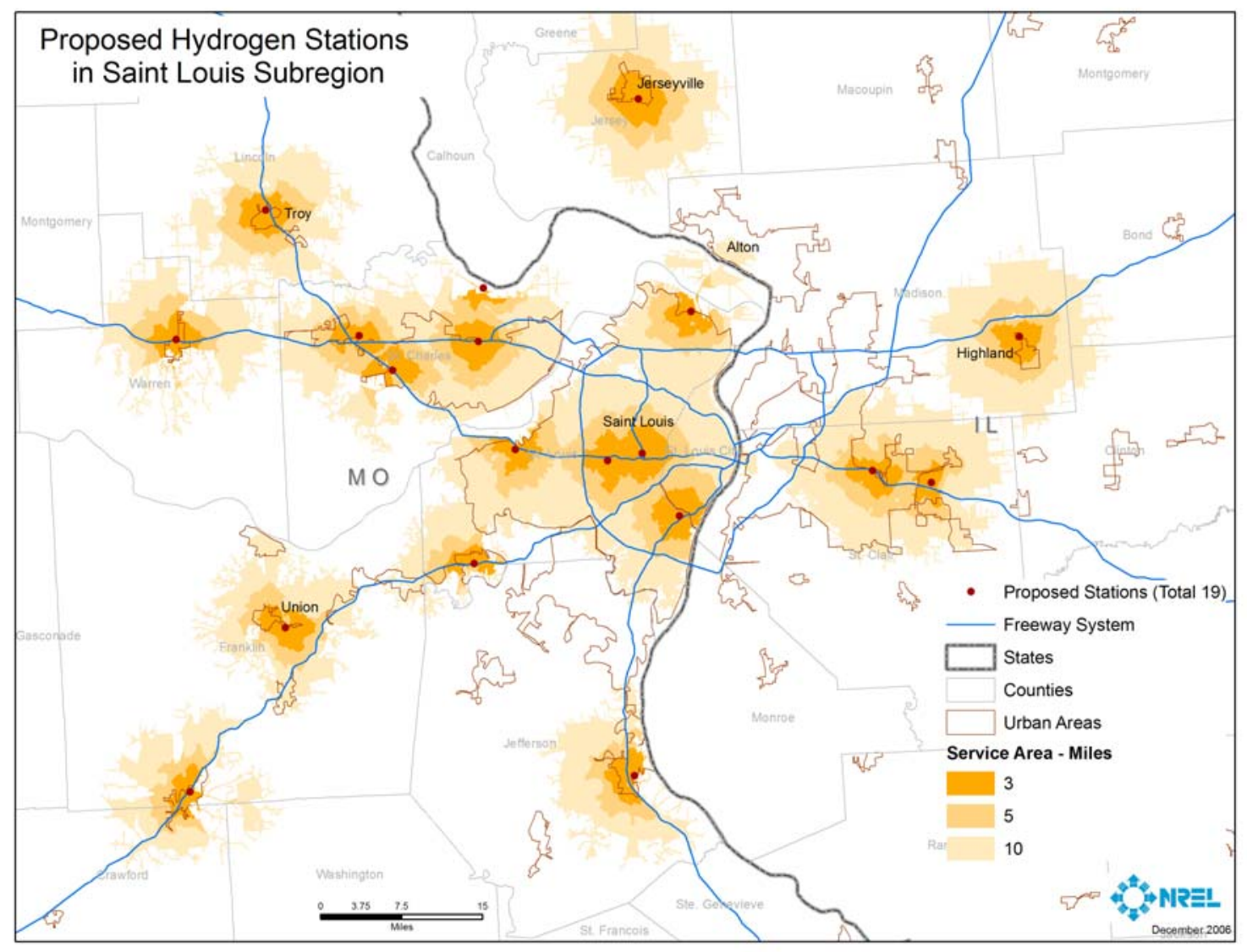

Figure 15. Proposed Hydrogen Stations in St. Louis Subregion 


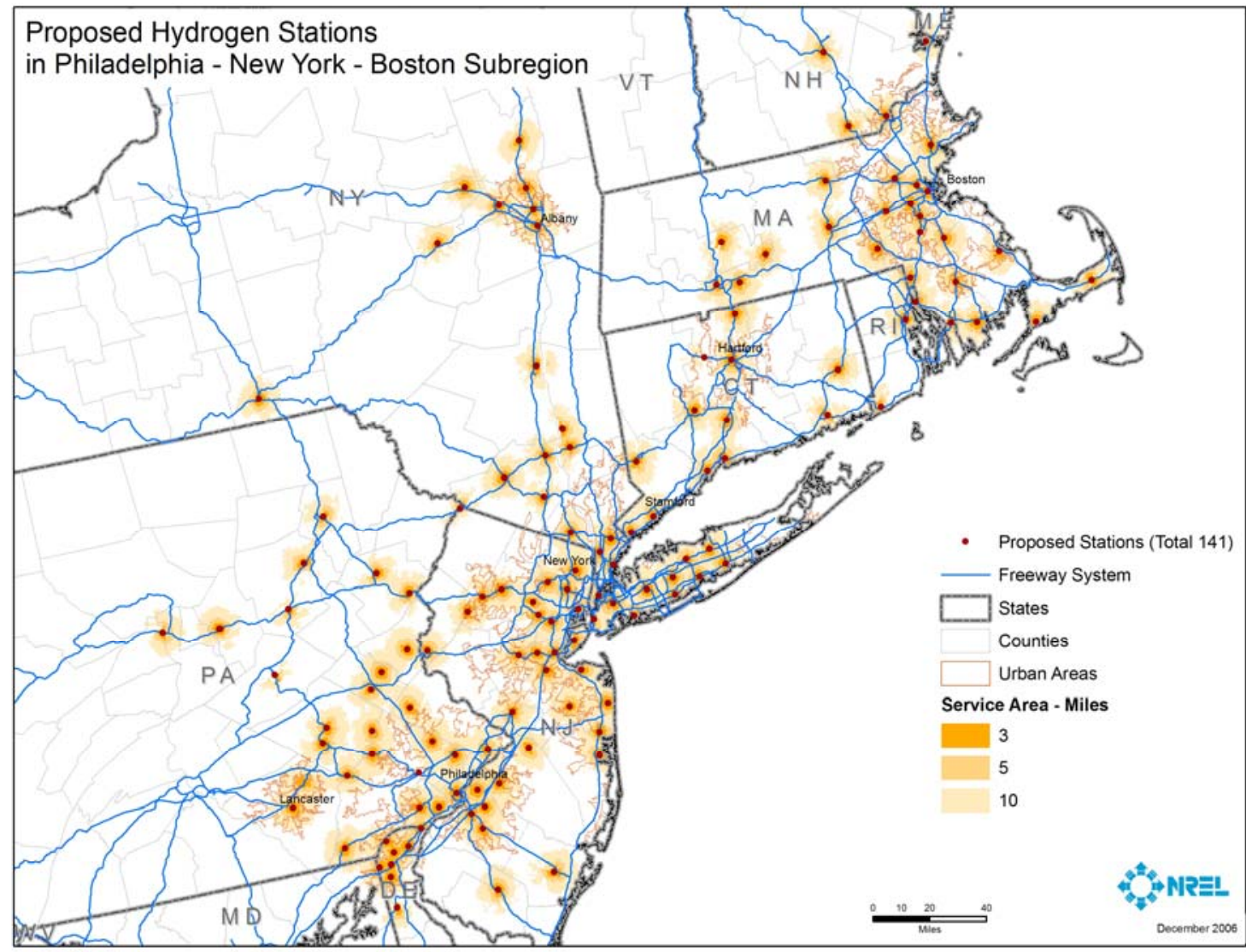

Figure 16. Proposed Hydrogen Stations in Philadelphia - New York - Boston Subregion 


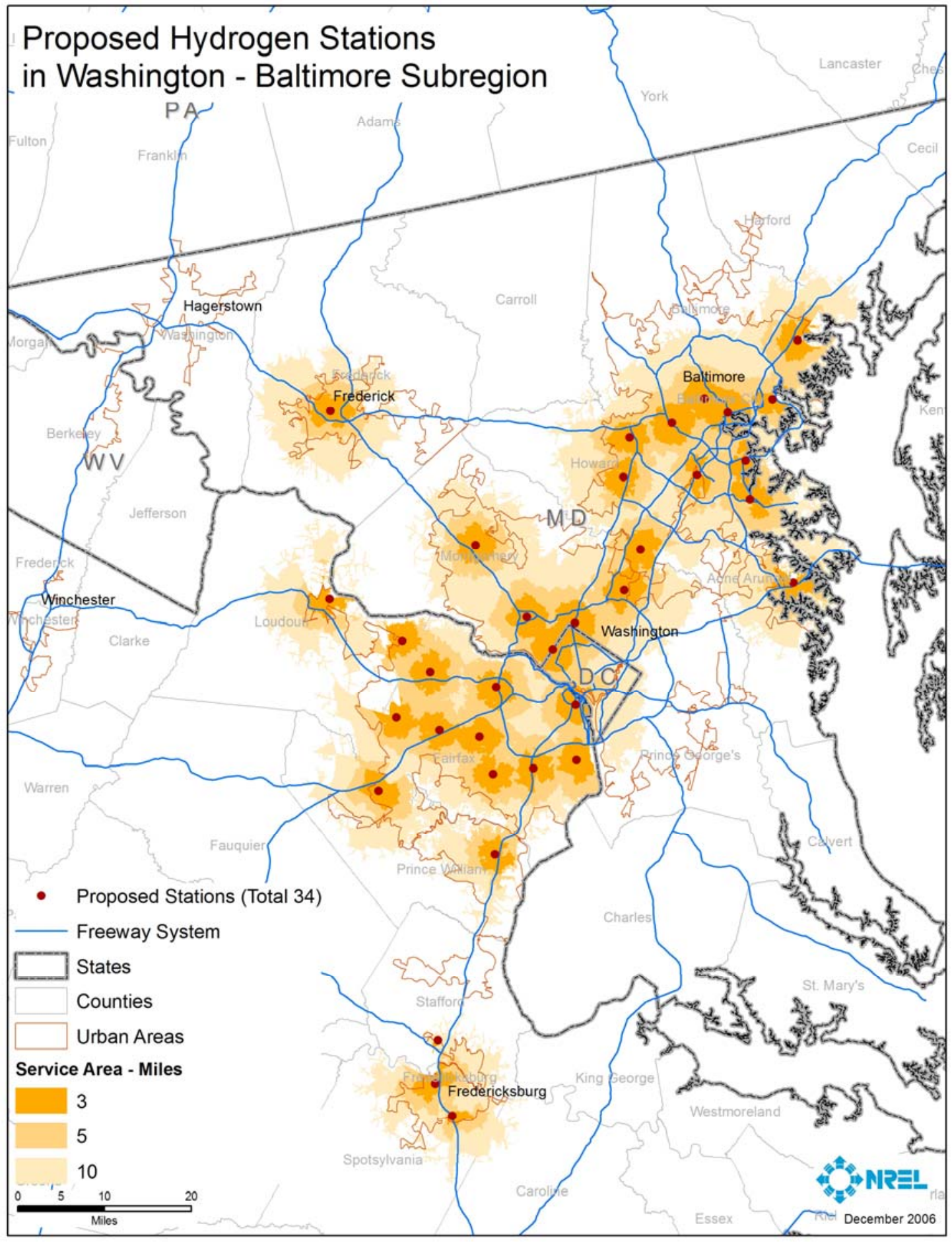

Figure 17. Proposed Hydrogen Stations in Washington - Baltimore Subregion 


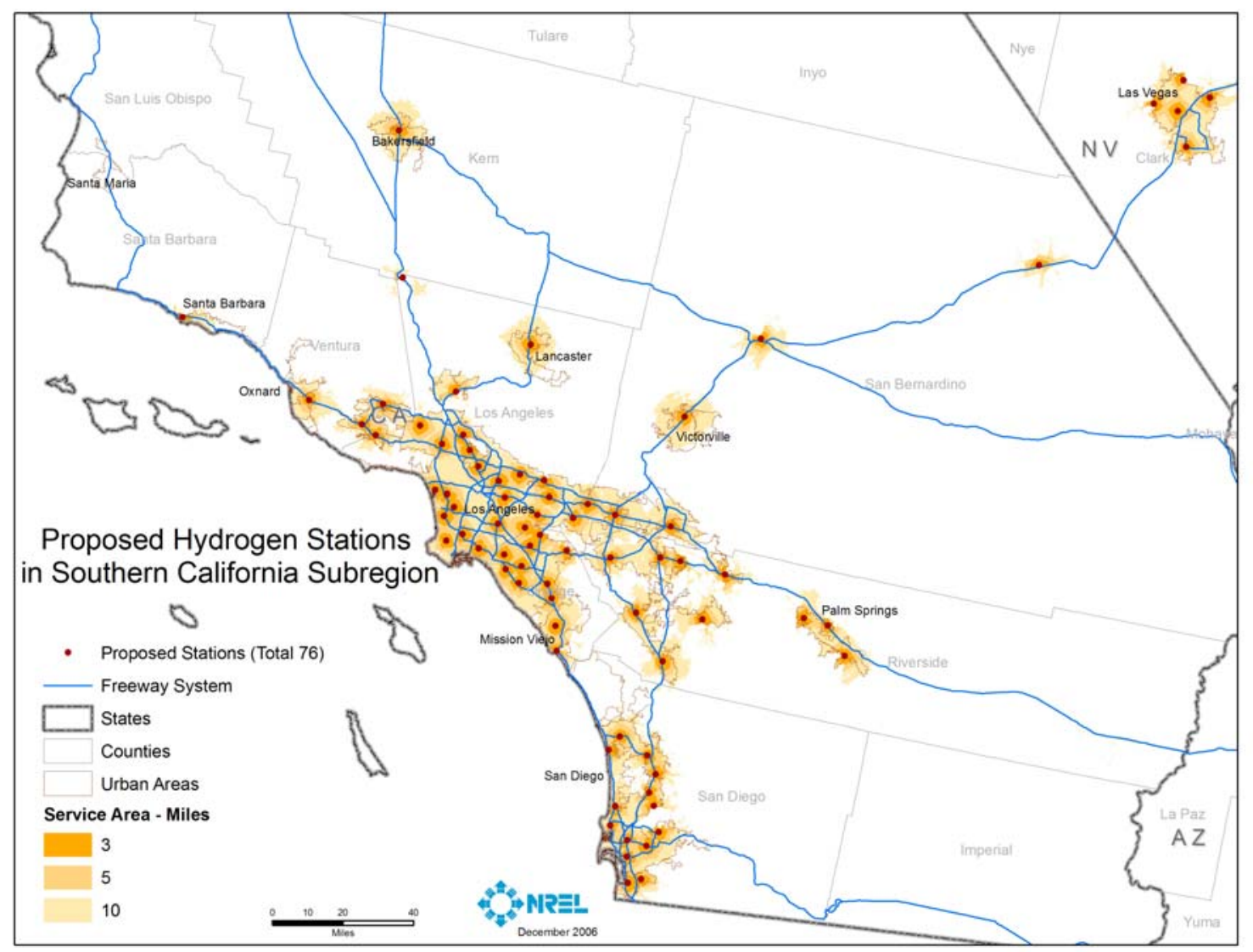

Figure 18. Proposed Hydrogen Stations in Southern California Subregion 


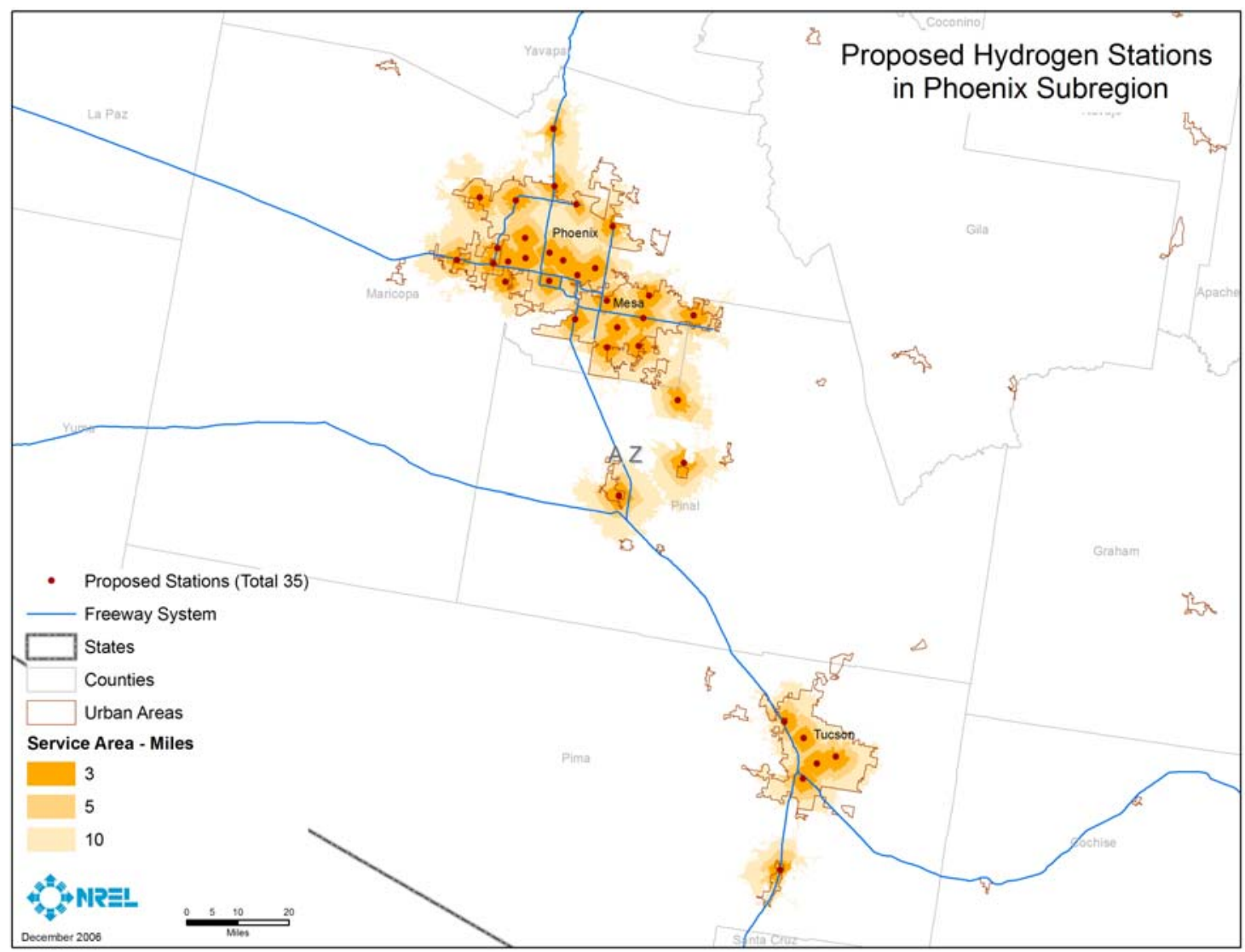

Figure 19. Proposed Hydrogen Stations in Phoenix Subregion 


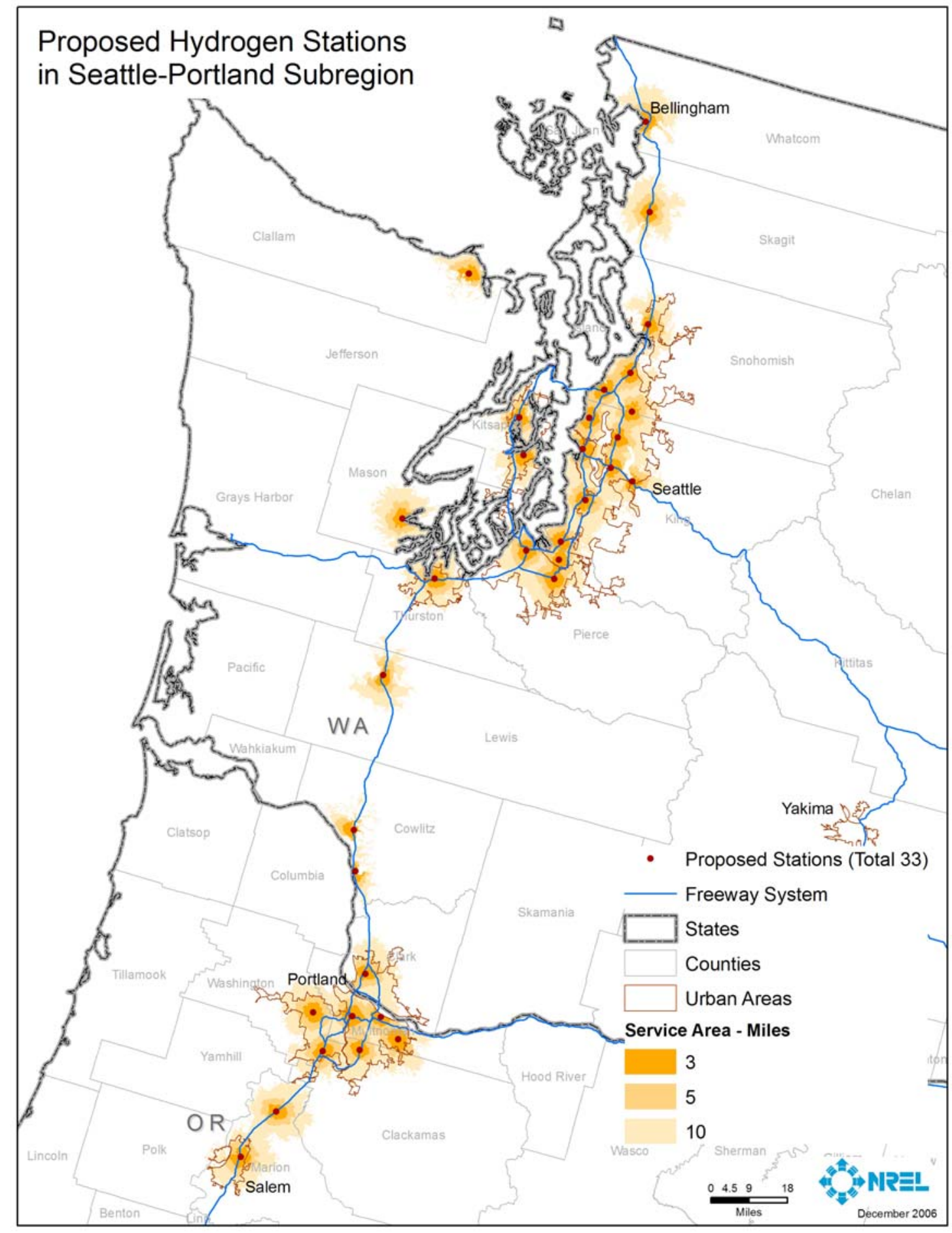

Figure 20. Proposed Hydrogen Stations in Seattle - Portland Subregion 


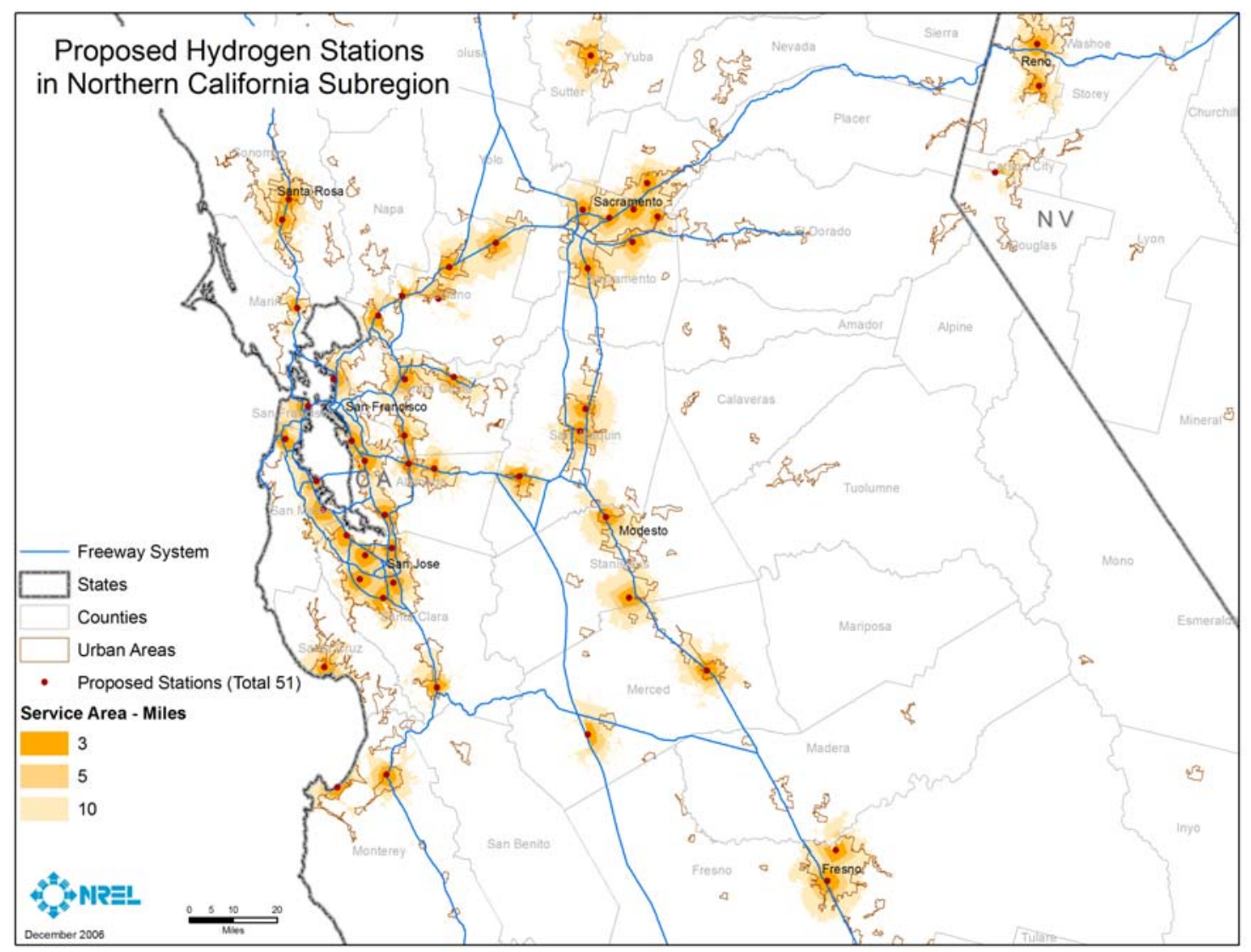

Figure 21. Proposed Hydrogen Stations in Northern California Subregion 


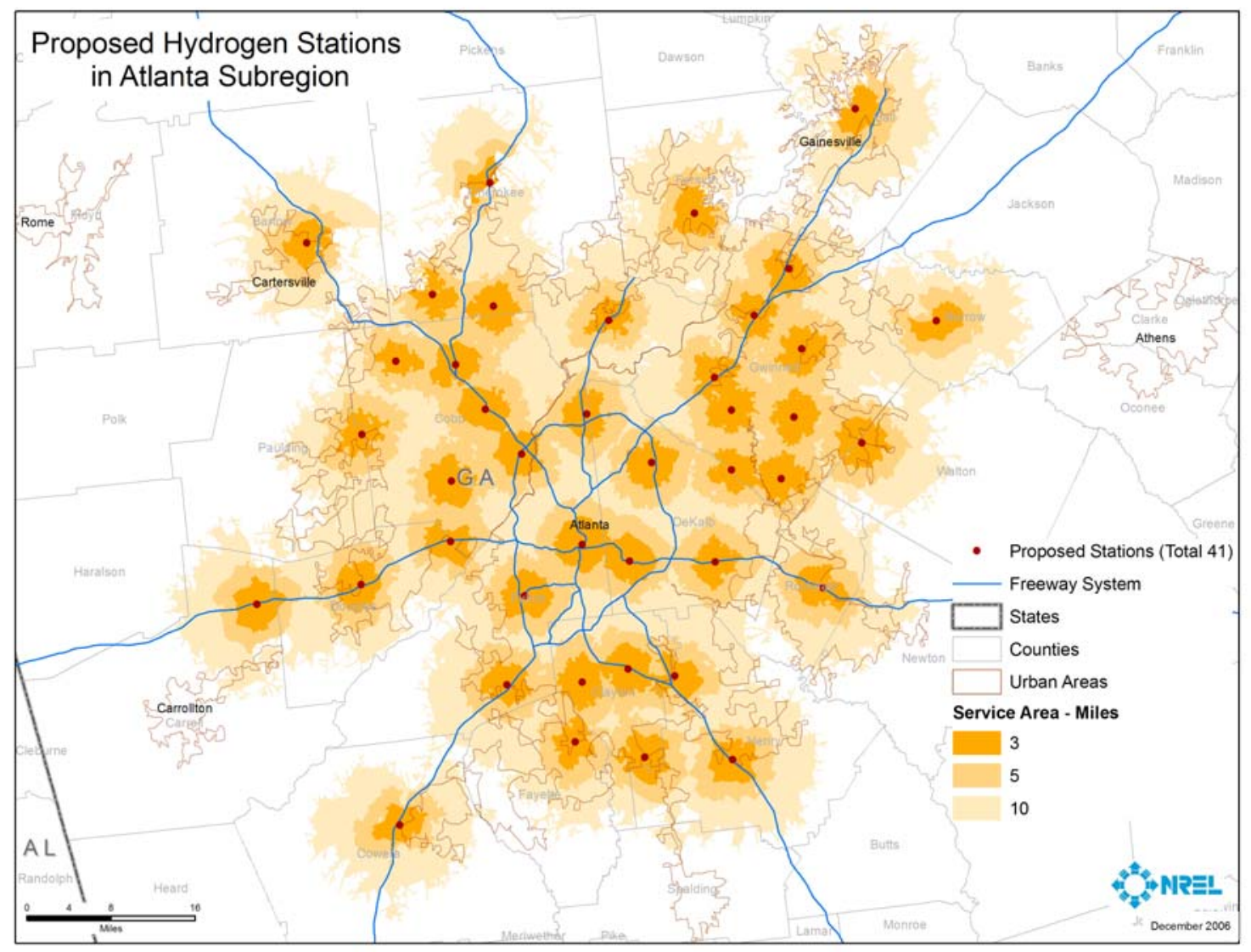

Figure 22. Proposed Hydrogen Stations in Atlanta Subregion

These figures show the customized station placements required to match the unique hydrogen demand characteristics of each urban area. Some subregions are strongly aligned with geographic features, such as Denver (Figure 9) and Salt Lake City's (Figure 11) alignment with adjacent mountains (and Great Salt Lake in Utah), giving them an asymmetrical, almost linear demand distribution. Some subregions have multiple distinct demand centers, such as East Texas (Figure 10, with centers in Houston, Dallas - Fort Worth, and San Antonio) and Seattle - Portland (Figure 20). Atlanta (Figure 22) and St. Louis (Figure 15) are examples of symmetrical demand distributions.

Table 11 lists hydrogen station coverage by subregion. There is considerable variability among subregions with respect to the proportion of their populations located within 3 and 5 miles of a proposed station, indicating how closely the population distribution of the subregions matches the hydrogen demand and station placement criteria used in this study. All the subregions have 90\%-99\% (average 95\%) of their populations within 10 miles of a proposed station. In areas that are more densely populated, the total number of people per station is greater than in the subregions less densely populated. As vehicles deploy, in areas where there are many people per station, additional stations may be necessary in the immediate area. Although the proportion of a subregion's population with access to a station is an interesting metric, the methods and criteria used in this study 
to site stations are the most valuable aspect of the project because it gives a good picture of where the greatest hydrogen demand is likely to be.

Table 11. Proposed Subregional Hydrogen Station Coverage

\begin{tabular}{|c|c|c|c|c|c|c|}
\hline \multirow{2}{*}{ Subregion } & \multirow{2}{*}{ Population } & \multirow{2}{*}{$\begin{array}{c}\text { Number } \\
\text { of } \\
\text { Stations }\end{array}$} & \multirow{2}{*}{$\begin{array}{l}\text { Stations } \\
\text { per Million } \\
\text { People }\end{array}$} & \multicolumn{3}{|c|}{$\begin{array}{l}\text { Population within } \\
\text { Distance of a Station }\end{array}$} \\
\hline & & & & $3 \mathrm{mi}$ & $5 \mathrm{mi}$ & $10 \mathrm{mi}$ \\
\hline Denver & $3,463,445$ & 33 & 9.5 & $49 \%$ & $84 \%$ & $96 \%$ \\
\hline East Texas & $15,512,273$ & 143 & 9.2 & $36 \%$ & $65 \%$ & $90 \%$ \\
\hline Salt Lake City & $1,903,127$ & 23 & 12.1 & $57 \%$ & $87 \%$ & $97 \%$ \\
\hline Chicago & $11,714,972$ & 62 & 5.3 & $26 \%$ & $56 \%$ & $96 \%$ \\
\hline Detroit & $5,919,388$ & 33 & 5.6 & $23 \%$ & $53 \%$ & $91 \%$ \\
\hline Minneapolis - St. Paul & $2,547,509$ & 14 & 5.5 & $23 \%$ & $54 \%$ & $92 \%$ \\
\hline St. Louis & $2,288,078$ & 19 & 8.3 & $21 \%$ & $46 \%$ & $94 \%$ \\
\hline Phil - New York - Boston & $37,451,570$ & 141 & 3.8 & $25 \%$ & $56 \%$ & $93 \%$ \\
\hline Washington-Baltimore & $6,389,207$ & 34 & 5.3 & $38 \%$ & $70 \%$ & $96 \%$ \\
\hline Southern California & $20,730,299$ & 76 & 3.7 & $36 \%$ & $72 \%$ & $98 \%$ \\
\hline Phoenix & $3,915,528$ & 35 & 8.9 & $53 \%$ & $87 \%$ & $99 \%$ \\
\hline Seattle - Portland & $5,457,743$ & 33 & 6.0 & $31 \%$ & $66 \%$ & $97 \%$ \\
\hline Northern California & $11,131,278$ & 51 & 4.6 & $36 \%$ & $67 \%$ & $93 \%$ \\
\hline Atlanta & $4,095,659$ & 41 & 10.0 & $37 \%$ & $74 \%$ & $97 \%$ \\
\hline
\end{tabular}

\section{Conclusions}

Using a GIS approach to spatially analyze key attributes affecting hydrogen market transformation, this study proposes hypothetical hydrogen refueling station locations in select subregions to demonstrate a method for determining station locations based on geographic criteria. These stations represent the locations that provide access within 10 miles for at least $90 \%$ of the population in the sub-regions. This represents a minimum hydrogen infrastructure needed to provide consumers access to fueling and make purchasing hydrogen vehicles a possibility.

The maps of estimated hydrogen demand and proposed hydrogen station locations show unique patterns among U.S. urban areas. There is no one-size-fits-all solution. Each area's unique demand characteristics should be considered to maximize the effectiveness of a limited initial hydrogen infrastructure Optimizing the match between emerging hydrogen demand and emerging infrastructure is critical to a successful transition to hydrogenpowered transportation. The methods used in this study represent a good process for identifying and capturing these unique geographic characteristics regarding market transformation.

\section{Future Work}

The station locations identified in this project demonstrate a scenario that provides access to a majority of potential early adopters of hydrogen vehicle technology, but does not explore the actual volume of hydrogen demand at each location nor the feasibility of 
siting a station in these locations. Issues such as the land availability, zoning and permitting requirements, natural gas or other feedstock availability and distribution should be explored as a next step analysis in support of hydrogen transition. 


\section{Bibliography}

Baxley, P.; Verdugo-Peralta, C.; Weiss, W. California Hydrogen Highway Network

Rollout Strategy Topic Team. Sacramento, CA: California Hydrogen Highway Network, November 2004.

Baxter-Clemmons, S. "California Hydrogen Highway Network Rollout Strategy" [Presentation]. Sacramento, CA: California Environmental Protection Agency, 2005.

Brown, M.H.; Breckenridge, L. State Alternative Fuel Vehicle Incentives: A Decade and More of Lessons Learned. Item \#4151. Denver, CO: National Conference of State Legislatures, February 2001.

California Environmental Protection Agency. California Hydrogen Blueprint Plan, Volume 1. Sacramento, CA: California Environmental Protection Agency, May 2005.

Code of Federal Regulations, 10 CFR Part 490. Alternative Fuel Transportation Program: Private and Local Government Fleet Determination. Washington, DC: U.S. Government Printing Office, January 2004.

CONEG Policy Research Center. Refueling Alternative Fuel Vehicles: Lessons Learned from the Marketplace. Washington, DC: Coalition of Northeastern Governors, 1995.

DeCicco, J.; Bernow, S.; Gordon, D.; Goldstein, D.; Holtzclaw, J.; Ledbetter, M.; Miller, P.; Sachs, H. "Transportation on a Greenhouse Planet: A Least-Cost Transition Scenario for the United States." T931. Washington, DC: American Council for an Energy-Efficient Economy, 1993.

DeCicco, J.M. "Fuel Cell Vehicles: Technology, Market, and Policy Issues." Future Car Congress; June 2002, Hyatt Crystal City, Virginia. 2002-01-1973. Warrendale, PA: Society of Automotive Engineers, June 2002.

DeCicco, J.M. "The 'Chicken or Egg' Problem Writ Large: Why a Hydrogen Fuel Cell Focus is Premature," Chapter 15. Sperling, D., Cannon, J., eds. The Hydrogen Energy Transition. St. Louis, MO: Elsevier Academic Press, 2004.

Greene, D.L.; Leiby, P.N.; Bowman, D.C. "Cost and Impacts of Policies." Presentation at Scenario Analysis for Hydrogen Fuel Cell Vehicles and Infrastructure, Washington, DC, January 31, 2007.

Greene, D.L.; Leiby, P.N.; Bowman, D.C. Integrated Analysis of Market Transformation Scenarios with HyTrans. ORNL Report No. ORNL/TM-2007/094. Oak Ridge, TN: Oak Ridge National Laboratory, 2007. 
Jackson, M.D.; Kaahaaina, N.; Fable, S. "Lessons Learned from Past Strategies to Reduce Petroleum Dependence." Presentation to the California Air Resources BoardCalifornia Energy Commission Staff Workshop on California Strategy on Petroleum Dependence, Sacramento, CA, September 2001.

Kurani, K.; Heffner, R.; Turrentine, T. "Consumers and Hybrids." Presentation to SAE Hybrid Vehicle Technology Forum, February 2006.

Leiby, P.; Rubin, J. "Transition Modeling of AFVs and Hybrids: Lessons Learned." Presentation at the Asilomar Conference Center, Pacific Grove, CA, July 2005.

Leiby, P.; Rubin, J. "Understanding the Transition to New Fuels and Vehicles: Lessons Learned from Analysis and Experience of Alternative Fuel and Hybrid Vehicles," Chapter 14. Sperling, D., Cannon, J., eds. The Hydrogen Energy Transition. St. Louis, MO: Elsevier Academic Press, 2004.

McCormick, G.L.; Russell, R.B. Alternative Bus Fuels: What Have We Learned. Camp Hill, PA: Gannett Fleming.

McNutt, B.; Rodgers, D. "Lessons Learned from 15 Years of Alternative Fuels Experience, 1988 to 2003," Chapter 12. Sperling, D., Cannon, J., eds. The Hydrogen Energy Transition. St. Louis, MO: Elsevier Academic Press, 2004.

Miller, Scott; "Consumer Requirements for a Hydrogen Fueling Infrastructure: Findings from a Six Month In-Market Simulation," Presentation to EVS 20, December 2003.

Nesbitt, K.; Sperling, D. Myths Regarding Alternative Fuel Vehicle Demand by LightDuty Vehicle Fleets. UCD-ITS-REP-98-09. Davis, CA: University of California, Davis Institute of Transportation Studies, July 1998.

Parish, R. "Implementing Alternative Fuels in Transportation Vehicles" [Abstract]. Golden, CO: National Renewable Energy Laboratory, 2005.

Patterson, P.; Alson, J.; Lance, L.; Brown, K.; Hawkins, D.; Ditlow, C.; Dana, G. "Lessons from 30 Years of Automotive Energy and Air Quality Policy: An Interactive Round Table." Davis, CA: University of California, Davis Institute of Transportation Studies, 1999.

Research Reports International. The Market for Alternative Fuel Vehicles. Evergreen, CO: Research Reports International, 2004.

Robertson, B.I.; Beard, L.K. "Lessons Learned in the Deployment of Alternative Fueled Vehicles," Chapter 13. Sperling, D., Cannon, J., eds. The Hydrogen Energy Transition. St. Louis, MO: Elsevier Academic Press, 2004. 
Santini, D.J.; Vyas, A.D. "How is Technology Adopted? A Discussion of Hybrid-Electric and Diesel Technology Consumer Preferences.” Argonne, IL: Argonne National Laboratory, 2004.

Schulte, I.; Hart, D.; van der Vorst, R. "Issues Affecting the Acceptance of Hydrogen Fuel.” International Journal of Hydrogen Energy; Vol. 29, 2003; p. 677.

U.S. Department of Energy. A National Vision of America's Transition to a Hydrogen Economy - to 2030 and Beyond. Washington, DC: U.S. Department of Energy, February 2002.

U.S. Department of Energy. Clean Cities 2004 Roadmap. Washington, DC: U.S. Department of Energy, 2004.

Unnasch, S.; Rutherford, D. "Policy Options for Hydrogen Vehicles and Infrastructure." Presentation at Scenario Analysis for Hydrogen Fuel Cell Vehicles and Infrastructure, Washington, DC, January 31, 2007.

Wells, J. "Alternative Motor Fuels Impact on the Transportation Sector." Testimony before Committee on Finance, U.S. Senate, July 10, 2001.

Wells, J. "Research and Development, Lessons Learned from Previous Research Could Benefit FreedomCar Initiative.” Testimony before the U.S. House of Representatives, June 6, 2002.

Wells, J. Energy Policy Act of 1992: Limited Progress in Acquiring Alternative Fuel Vehicles and Reaching Fuel Goals. GAO/RCED-00-59. Washington, DC: U.S. General Accounting Office, February 2000.

Zhao, J.; Melaina, M.W. "Transition to Hydrogen-Based Transportation in China: Lessons Learned from Alternative Fuel Vehicle Programs in the United States and China.” Energy Policy; Vol. 34, 2006; p. 1299. 


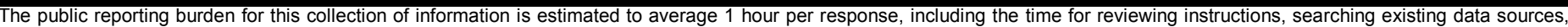

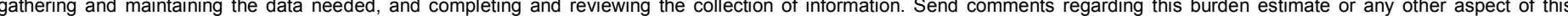

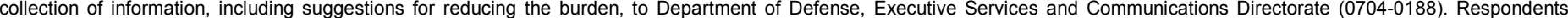

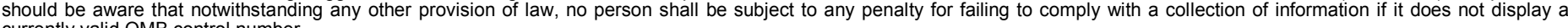
currently valid OMB control number.

PLEASE DO NOT RETURN YOUR FORM TO THE ABOVE ORGANIZATION

\section{REPORT DATE (DD-MM-YYYY) \\ April 2008 \\ 2. REPORT TYPE \\ Technical Report}

4. TITLE AND SUBTITLE

Regional Consumer Hydrogen Demand and Optimal Hydrogen

Refueling Station Siting

3. DATES COVERED (From - To)

5a. CONTRACT NUMBER

DE-AC36-99-G010337

5b. GRANT NUMBER

5c. PROGRAM ELEMENT NUMBER

5d. PROJECT NUMBER

NREL/TP-540-42224

5e. TASK NUMBER

$\mathrm{H} 2782700$

5f. WORK UNIT NUMBER

7. PERFORMING ORGANIZATION NAME(S) AND ADDRESS(ES)

National Renewable Energy Laboratory

1617 Cole Blvd.

Golden, CO 80401-3393
8. PERFORMING ORGANIZATION REPORT NUMBER

NREL/TP-540-42224

9. SPONSORING/MONITORING AGENCY NAME(S) AND ADDRESS(ES)

10. SPONSOR/MONITOR'S ACRONYM(S) NREL

11. SPONSORING/MONITORING AGENCY REPORT NUMBER

\section{DISTRIBUTION AVAILABILITY STATEMENT}

National Technical Information Service

U.S. Department of Commerce

5285 Port Royal Road

Springfield, VA 22161

\section{SUPPLEMENTARY NOTES}

14. ABSTRACT (Maximum 200 Words)

Using a GIS approach to spatially analyze key attributes affecting hydrogen market transformation, this study proposes hypothetical hydrogen refueling station locations in select subregions to demonstrate a method for determining station locations based on geographic criteria.

\section{SUBJECT TERMS}

hydrogen demand; hydrogen analysis; hydrogen refueling station; hydrogen infrastructure

\begin{tabular}{|c|c|c|}
\hline \multicolumn{3}{|c|}{ 16. SECURITY CLASSIFICATION OF: } \\
\hline $\begin{array}{l}\text { a. REPORT } \\
\text { Unclassified }\end{array}$ & $\begin{array}{l}\text { b. ABSTRACT } \\
\text { Unclassified }\end{array}$ & $\begin{array}{l}\text { c. THIS PAGE } \\
\text { Unclassified }\end{array}$ \\
\hline
\end{tabular}

17. LIMITATION
OF ABSTRACT
UL

18. NUMBER
OF PAGES

19a. NAME OF RESPONSIBLE PERSON

19b. TELEPONE NUMBER (Include area code) 